\title{
Ground beetles (Carabidae) as seed predators
}

\author{
AloIs HONEK ${ }^{1}$, ZDENKA MARTINKOVA ${ }^{1}$ and VOJTECH JAROSIK ${ }^{2}$
}

\begin{abstract}
${ }^{1}$ Research Institute of Crop Production, Drnovská 507, CZ 16106 Prague 6 - Ruzyně, Czech Republic; e-mail: honek@vurv.cz; martinkova@vurv.cz

${ }^{2}$ Faculty of Science, Charles University, Viničná 7, CZ 12000 Prague 2, Czech Republic; jarosik@mbox.cesnet.cz
\end{abstract}

\begin{abstract}
Key words. Carabidae, seed, predation, herb, weed, preference, consumption, abundance, crop, season
\end{abstract}
\begin{abstract}
The consumption and preferences of polyphagous ground beetles (Coleoptera: Carabidae) for the seeds of herbaceous plants was determined. The seeds were stuck into plasticine in small tin trays and exposed to beetle predation on surface of the ground. In the laboratory the effect of carabid (species, satiation) and seed (species, size) on the intensity of seed predation was investigated. The consumption of the generally preferred Cirsium arvense seed by 23 species of common carabids increased with body size. Seed of Capsella bursa-pastoris was preferred by small carabids and their consumption rates were not related to their size. The average daily consumption of all the carabid species tested $\left(0.33 \mathrm{mg}\right.$ seeds . $\mathrm{mg}$ body mass ${ }^{-1}$. day $\left.{ }^{-1}\right)$ was essentially the same for both kinds of seed. Because of satiation the consumption of seed of C. arvense provided ad libitum to Pseudoophonus rufipes decreased over a period of 9 days to $1 / 3-1 / 4$ of the initial consumption rate. Preferences of $P$. rufipes (body mass $29.6 \mathrm{mg}$ ) and Harpalus affinis $(13.4 \mathrm{mg})$ for the seeds of 64 species of herbaceous plants were determined. The small $H$. affinis preferred smaller seed than the large P. rufipes. Predation of seed present on the ground in the field was studied in 1999-2000, at PrahaRuzyne $\left(50^{\circ} 06^{\prime} \mathrm{N} 14^{\circ} 16^{\prime} \mathrm{E}\right)$. Seeds were placed in stands of different crops as in the laboratory experiments and vertebrate predation was excluded by wire mesh cages. Pitfall traps placed near the cages revealed that carabids were the only seed predators active in the area. Rates of removal of seed of 6 weed species varied with crop, season, seed and site. Average rate of removal in June-August was 2.5 seeds.day ${ }^{-1}$.tray ${ }^{-1}$ and was smaller before and after this period. The rates of removal increased with increasing activity density of the carabids and paucity of seed from naturally occurring weeds, which may have satiated the carabids. In stands of winter wheat, millet and soybeans there were significant differences in the rates of removal of the seed of 43 herbaceous species. The field preferences were correlated with those established in the laboratory. Predation of seed on the ground in arable fields can be as high as 1000 seeds. $\mathrm{m}^{-2}$.day ${ }^{-1}$ and may selectively influence the quantity of seed of particular herb species that enters the soil seed bank. Seed predation thus may be an effective component of weed control on arable land, particularly at low weed densities.
\end{abstract}

\section{INTRODUCTION}

Angiosperm seed is dispersed in space by wind, water or animals, before entering the soil seed bank where it may persist for many years. In seed dispersal, predation is an important mortality factor (Harper, 1977; Crawley, 1992; Marone et al., 2000; Maron \& Gardner, 2000). Large, mobile and generalist predators, like rodents or birds tend to seek large seed (Coates-Estrada \& Estrada, 1988; Crawley, 1997). The small seed of herbaceous plants is eaten by both vertebrate and invertebrate predators (Price \& Jenkins, 1986; Brust \& House, 1988; Louda, 1989; Louda et al., 1990; Marino et al., 1997; Hulme, 1998; Swanton et al., 1999; Menalled et al., 2000; Westerman et al., 2003). Among invertebrates, the most important predators of seed are ants (Hölldobler \& Wilson, 1990). "Harvesting ants", mostly species of the subfamily Myrmicinae, inhabit tropical and subtropical regions, and are occasional to obligatory seed eaters. Their seed collecting may alter the abundance and local distribution of flowering plants (Brown et al., 1979; Andersen, 1982; Risch \& Carroll, 1986). Less important predators include Coleoptera (e.g. Ramirez \& Arroyo, 1987), Heteroptera (Andersen \& Ashton, 1985; Socha, 1993), Orthoptera (Carmona et al., 1999) and other invertebrate species (Reader \& Beisner, 1991; Reader, 1991; Cardina et al., 1996).
In the temperate zone probably the most important seed eaters are ground beetles (Carabidae: Coleoptera). In the Czech Republic this family is represented by more than 550 species (Hurka, 1996). The species characteristic of arable land are capable of withstanding agricultural practices (Luff, 1987; Holland \& Luff, 2000), often disappear when the fields are abandoned (Van Dijk, 1987) and their distribution is patchy and temporarily unstable (Kinnunen \& Tiainen, 1999; Thomas et al., 2001).

Carabid diet has been studied in the field and laboratory, and by stomach dissections (Davies, 1953; Skuhravy, 1959; Dawson, 1965). Ground beetles accept a range of animal prey but some of them also eat plant material (leaves, fruits and pollen) and fungi (Johnson \& Cameron, 1969). A number of investigations (reviewed by Thiele, 1977; Hengeveld, 1980a; Luff, 1987; Lövei \& Sunderland, 1996; Kromp, 1999; Toft \& Bilde, 2002) have distinguished two categories of phytophagous ground beetles, those that are normally carnivorous but supplement their diets with the vegetative parts of plants, and those that mainly eat seeds (Brandmayr, 1990).

The eating of seeds by carabids (granivory) was first recorded more than 100 years ago (Forbes, 1883; Webster, 1900) and confirmed since by many authors (Burmeister, 1939; Lindroth, 1949; Burakowski, 1967; Johnson \& Cameron, 1969; Kirk, 1972; Best \& Beegle, 1977; Lund \& Turpin, 1977; Luff, 1980; Kjellsson, 1985; 
Brust \& House, 1988; Trautner et al., 1988; Manley, 1992; Goldschmidt \& Toft, 1997; Jørgensen \& Toft, 1997a, b; Zhang et al., 1997; Hartke et al., 1998; Harrison et al., 2003). Carabid granivory is thus a well established phenomenon (Allen, 1979; Hengeveld, 1980b; Luff, 1987; Lövei \& Sunderland, 1996; Kromp, 1999; Tooley \& Brust, 2002). Although its occurrence is well documented quantitative data on granivory are relatively scarce. The early reports frequently mention the consumption of seeds of Gramineae (Johnson \& Cameron, 1969). Thiele (1977) concluded that Amara spp. prefer the seeds of Cruciferae and Harpalus spp. to those of Umbelliferae. Recent papers reveal they eat the seeds of a number of plant species belonging to many families (Goldschmidt \& Toft, 1997; Tooley et al., 1999; Lietti et al., 2000) and that some species can complete their larval development on a diet of seeds (Jørgensen \& Toft, 1997b; Hurka, 1998; Saska \& Jarosik, 2001). Additionally, many species even cache seeds underground and may live on them for some time (Schremmer, 1960; Manley, 1971). The importance of plant seeds as a food is indicated by their attractiveness to carabids, which aggregate where seeds are abundant (Kokta, 1988; Kromp, 1990; Honek \& Jarosik, 2000; Honek \& Martinkova, 2001; Volkmar et al., 2001). When searching for seed, adult beetles are known to climb plants, particularly grasses and umbellifers (Hurka, 1996). Some species even feed on unripe seeds in maturing rape siliquas (Luka et al., 1998). However, many species do not climb plants (Lövei \& Szentkiralyi, 1984) and most seed is probably collected on the ground.

Despite the interest in this topic there is no comparative study of the preferences using many carabid and seed species. We therefore made this study of the seed preferences and consumption under controlled and field conditions. The assumption that body size of the beetles and size of the seed determine the rates of seed consumption and preferences of carabid species was tested in the laboratory. To test the role of seed and carabid body size we examined (i) the rate of consumption of the seed of 2 species in relation to the body mass and level of satiation of several carabid species, and (ii) preferences of 2 carabid species of different body size for seed of different mass. In the field the role of carabids as predators of shed seeds was studied in order to establish whether (iii) carabids remove a significant proportion of the seed on the surface of the soil, (iv) the quantity of seed removed varies with carabid abundance and season, and (v) the predation on different seed species is selective.

\section{MATERIAL AND METHODS}

\section{Collecting and offering seed to carabid}

Seeds of 65 broadleaved herbaceous species, particularly weeds of agricultural crops, were used in the experiments (Appendix 1). The seeds were collected in 1996 at localities in Bohemia (Martinkova et al., 1997), air dried, and stored at $24-26^{\circ} \mathrm{C}$ and $40 \%$ relative humidity until required. Appendages or perianths present on some seed at dispersal were removed. The quality of seed was thus "standardized" and removal experiments used "naked" seed similar to that present on the ground surface at the time of entering the soil seed bank. Seed mass was determined by weighing 100 oven dried "naked" seeds taken randomly from samples used in the experiments. Seed was exposed to carabid predation in small tin trays, $28 \mathrm{~mm}$ in diameter and $6 \mathrm{~mm}$ deep $\left(6.2 \mathrm{~cm}^{2}\right)$. The trays were filled with white plasticine (JOVI ${ }^{\circledR}$, Barcelona) and the seeds inserted into the plasticine. The number of seeds exposed on a tray depended on the size of the seed. Each tray contained 15 (Arctium lappa, Bidens tripartita, Galium aparine) or 30 seeds (other species). The trays were placed on the ground so that the plasticine surface was level with that of the soil. The seeds were thus accessible to beetles walking across the surface. After exposure to predation the numbers of intact seeds in each tray were counted using a lens with a 10 times magnification. Missing seeds and those of which $>50 \%$ was consumed were considered eaten.

\section{Laboratory experiments}

Carabids. Laboratory experiments were performed with mature adults collected in the field at the time of their maximum activity, using pitfall traps. Before the start of an experiment beetles were stored in the dark for 1-4 days, in 0.51 plastic bottles filled with folded moist filter paper, at temperatures of $5-7^{\circ} \mathrm{C}$. This prevented cannibalism and standardised the level of hunger of the experimental beetles. The beetles were not sexed because we were interested in estimating the predation rates in the field, which might be influenced by the sex ratios of the populations of the various carabids. All experimental individuals of a species were assumed to be of a typical size, with the average body length cited by Hurka (1996) and average dry body weight calculated using the formula of Jarosik (1989). To prevent repeated measure data each individual was used only once.

No choice experiments. Experiments were done in JulyAugust 1999 and 2000. The temperature ranged between $25-27^{\circ} \mathrm{C}$ and the relative humidity inside the experimental vials was $100 \%$. The photoperiod was natural (i.e. decreasing from $\mathrm{c}$. $17.5 \mathrm{~L}: 6.5 \mathrm{D}$ to $\mathrm{c} .15 \mathrm{~L}: 9 \mathrm{D})$ but the vials were screened from direct sunlight. The experimental arena consisted of a cylindrical glass tube $10 \mathrm{~cm}$ in diameter and $10 \mathrm{~cm}$ high, covered with a glass lid. Each tube contained a $2 \mathrm{~cm}$ of sieved soil (mesh diameter $4 \mathrm{~mm}$ ), which was dug from a depth of $>0.5 \mathrm{~m}$ and did not contain any seeds. The soil was moistened with $15 \mathrm{ml}$ tap water and a piece of moist cotton wool was provided as source of drinking water for the experimental animals. A tray of either Capsella bursa-pastoris or Cirsium arvense seed was placed in the center of an arena. One adult beetle was placed in an arena and its seed consumption recorded daily, for 3 days. When trays were emptied of their seeds they were replaced and the beetles thus provided with an abundant food supply during the whole experimental period. Twenty three species of carabid (Appendix 2 ), which were abundant in fields, were tested. The numbers of individuals of particular species used in the experiment were different because some species were scarce and/or laboratory space was limited.

To determine the effect of carabid satiation on seed consumption the same experimental design as described above was used to record the consumption of $C$. arvense seeds by Pseudoophonus rufipes over a period of 9 days, August 11-20, 1999. Ten arenas were used in the laboratory and 10 in the field, placed at ground level and shaded from direct sunlight and rain by a wooden construction. Each arena contained one adult beetle. Laboratory conditions were as cited above, the average field temperature over the period of the experiment was $20.2 \pm 2.6^{\circ} \mathrm{C}$, with a daily minimum of $11.4 \pm 2.1^{\circ} \mathrm{C}$ and maximum of $27.8 \pm$ $4.4^{\circ} \mathrm{C}$ at ground level. 
TABLE 1. Arrangement of the seeds in the laboratory experiments. Species indicated by numbers and as listed in Appendix 1. Italics: "reference" species used alternatively in experiments with $H$. affinis and $P$. pubescens (see Material and Methods).

\begin{tabular}{|c|c|}
\hline Series & Species \\
\hline \multicolumn{2}{|l|}{ Laboratory } \\
\hline \multicolumn{2}{|c|}{ Multichoice experiment } \\
\hline (i) & $4,13,18,21,23,29,42,51,58,65$ \\
\hline (ii) & $1,10,14,19,22,32,45,49,62$ \\
\hline (iii) & $12,16,26,33,36,41,54,59,63$ \\
\hline (iv) & $3,5,30,35,43,46,55,56,61$ \\
\hline$(\mathrm{v})$ & $9,11,15,20,37,44,47,50,52$ \\
\hline (vi) & $2,7,8,17,27,40,48,53,57$ \\
\hline (vii) & $6,24,25,28,31,34,38,39,60$ \\
\hline
\end{tabular}

Field

Standard series

$$
13,21,25,40,53,57
$$

Experiment 1

$$
\begin{aligned}
& 4,15,30,36,61,63 \\
& 24,38,42,53,58,64 \\
& 5,18,23,29,35,51 \\
& 17,39,41,43,47,55
\end{aligned}
$$

Experiment 2

$$
4,7,13,27,36,41
$$

$$
8,21,33,34,54,63
$$

$$
2,20,43,46,48,58
$$

Experiment 3

$\begin{array}{ll}\text { (i) } & 30,42,44,54,62,63 \\ \text { (ii) } & 20,22,27,28,35,43\end{array}$

Multichoice experiments. The preference of two of the carabid species, $P$. rufipes and Harpalus affinis, for the seed of 64 species of plant was established using multichoice experiments, which were made at the same time and under the same conditions as the no choice experiments. The tests were made in Petri dishes ( $250 \mathrm{~mm}$ in diameter and $50 \mathrm{~mm}$ height), each containing a $2 \mathrm{~cm}$ layer of sieved soil of the same quality as in the no choice experiments. The soil was moistened with $100 \mathrm{ml}$ tap water. Each Petri dish was also provided with a piece of moist cotton wool. Ten trays, each with the seed of a different species were placed in each Petri dish, arranged at random in a circle, at a distance of $3 \mathrm{~cm}$ from the edge of the Petri dish. In experiments using $P$. rufipes one of the 10 trays in each Petri dish contained the seeds of $C$. arvense as a "reference species". The other seeds were presented in series (i) - (vii) each consisting of seed of nine species (Table 1). Thus there were seven seed combinations and each seed combination was replicated 3 times. At the beginning of the experiment a group of 10 randomly selected adult beetles was placed in each Petri dish. These beetles were allowed to eat seed for 7 days. The removal of seed from each tray was recorded daily, but the seed was not replaced. Seed taken from trays but uneaten was returned to the trays. The seed preferences of $H$. affinis were tested in the same way as those of $P$. rufipes except that the "reference species" was not $C$. arvense but C. bursa-pastoris, because of the smaller size of $H$. affinis.

\section{Field experiments}

Experimental area. Field experiments on seed removal were conducted at Praha - Ruzyne $\left(50^{\circ} 06^{\prime} \mathrm{N} 14^{\circ} 16^{\prime} \mathrm{E}\right)$ where the average monthly temperatures in April to October are 7.9, 12.7, $16.3,17.6,16.8,13.2$ and $8.2^{\circ} \mathrm{C}$, and the average monthly precipitation are $36,57,64,70,60,32$ and $33 \mathrm{~mm}$, respectively. The experimental grounds were situated within a $1 \mathrm{~km}^{2}$ area located on a south facing slope ( $4 \%$ inclination), at an altitude of $330-360 \mathrm{~m}$. The experimental area is a mosaic of production and experimental fields divided by ridges and hedges, with a uniform soil quality. The crop rotation in the production fields was irregular, including different small grain cereals, oilseed rape, peas and alfalfa. All crops were grown using the standard practices recommended in the Czech Republic. No insecticides were used throughout the period of investigation.

Presenting seed. The seed placed in the open was presented in trays identical to those used in the laboratory except for a 25 $\mathrm{mm}$ long nail attached to the convex side, which prevented horizontal movement (Fig. 1A). The seeds were stuck in plasticine and in the same numbers as in the laboratory. The trays of seed were exposed in groups of six, each group was covered with a $18 \times 18 \times 9 \mathrm{~cm}$ wire mesh cage (mesh diameter $9 \mathrm{~mm}$, wire 1 $\mathrm{mm}$ thick), whose sides were inserted into the soil to a depth of $4 \mathrm{~cm}$ (Fig. 1B). The roof of each cage was shielded by $18 \times 18$ $\mathrm{cm}$ plastic plate wrapped in aluminium foil, which protected the trays from rain and direct sunlight. These cages prevented the access of vertebrates. Each tray in a cage contained seed of a different species.

Seed removal rates. Seasonal and between crop variation in removal rates were studied by exposing groups of trays with a "standard" series of seed of six species (Table 1, Fig. 1C). Series of 4, 6 (mostly) or 8 cages were placed simultaneously in a crop and exposed to seed predation for different periods of time. Nine series were exposed between July 19 and September 14,1999 , in crops of winter wheat, winter rape, maize, millet and on abandoned field. Thirty two series were exposed between April 18 and October 11, 2000 in 2 stands of winter wheat, 1 of winter rape and 1 of soybeans. To prevent bias when calculating the daily consumption rates the exposure of cages was always terminated before all the seeds of the preferred species were eaten. The length of exposure therefore varied between 3-20 days depending on the intensity of seed removal.

Seed preferences were studied in three experiments using the seed of 46 broadleaved herbaceous plants. "Experiment 1" (conducted between July 14-22, 1999, in winter wheat stand ) and "Experiment 2" (August 5-18, 1999, millet) consisted of 20 cages placed in a rectangular $5 \times 4$ grid, with $20 \mathrm{~m}$ between the cages (Fig. 1D). In both experiments four series (i - iv) of seeds (Table 1) replicated five times in each series were used (cages). "Experiment 3" (July 30-August 10, 2000, soybeans) consisted of two series of seeds (Table 1). The cages containing the different seeds were placed alternatively, in two rows at a spacing of $15 \mathrm{~m}$ (Fig. 1E).

Activity density of carabids. The activity density of the carabids around cages where seed was exposed was determined using 1 or 2 pitfall traps placed within $1 \mathrm{~m}$ of each cage. The pitfall traps were plastic cups, $7 \mathrm{~cm}$ in diameter $\left(38.5 \mathrm{~cm}^{2}\right.$ outlet area) and $8 \mathrm{~cm}$ deep. The cups were placed in the soil, with the rim at the soil surface, and screened from rain and direct sunlight by a dish wrapped in aluminium foil. No bait was used. A few lumps of soil at the bottom of the cups provided shelter for the trapped arthropods. The traps were emptied at 2 or 3 day (weekends) intervals. The beetles were determined to species, 

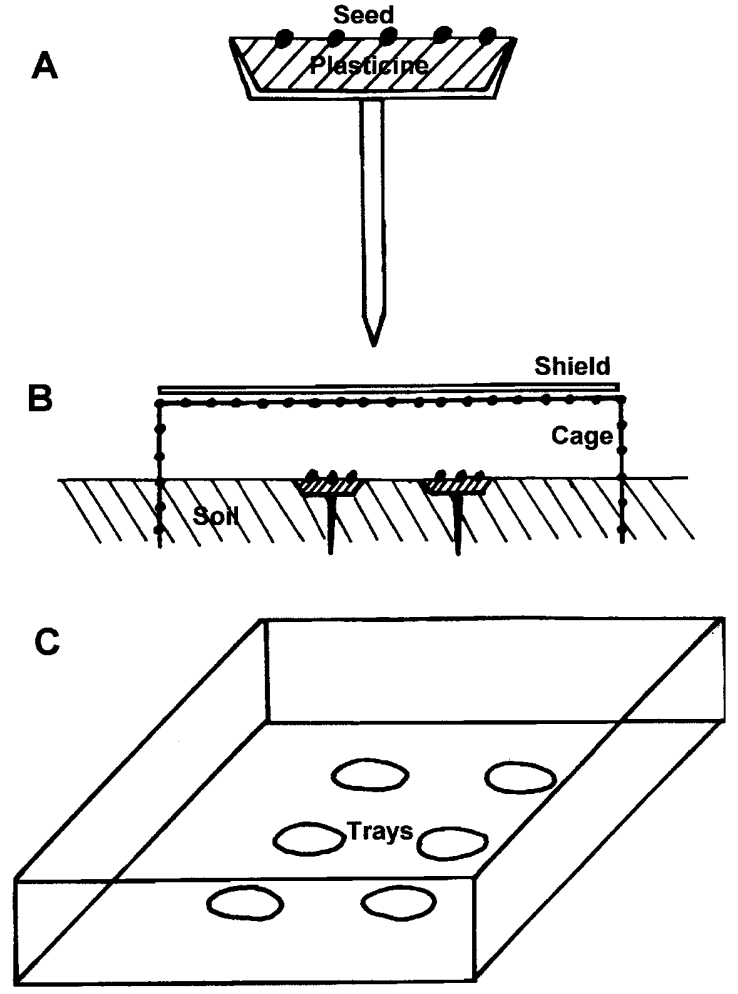

D
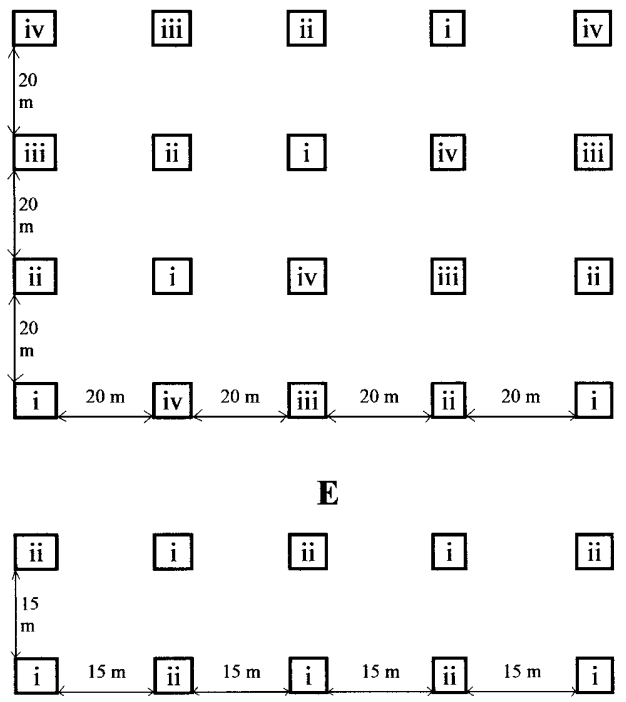

Fig. 1. Schematic representation of the method of offering seed to carabids in the field. A - tin tray filled with plasticine into which seeds were inserted; B - a section through a wire mesh cage inserted into the soil, protected by a shield, and with trays inserted into the soil; $\mathrm{C}$ - position of the trays in a field cage; D - arrangement of cages in "Experiment 1" and "Experiment 2" to test carabid preferences (each cage is labelled with the number of the series $\mathrm{i}$ - iv of seeds they contain, see Tab. 1); E - arrangement of cages in "Experiment 3".

counted and immediately released. A list of the carabid species caught is presented in Appendix 2.

Weed abundance. The abundance of seed producing weeds was determined in winter rape and winter wheat stands, where seeds were placed between June 2-26. Within each crop during this period the number of seed producing weed plants in $0.16 \mathrm{~m}^{2}$ $(0.4 \times 0.4 \mathrm{~m})$ plots were counted. In winter rape weeds were counted in 7 randomly selected plots. To compensate for their low abundance the weeds in winter wheat were counted in 20 plots.

\section{Data analysis}

Seed preferences. In the laboratory the rates of removal of seed were determined for either 30 or 15 seeds. The time of seed removal (in days) was the response variable, seed and carabid species factors, and replicates used as statistical blocks. Seeds remaining at the end of an experiment were censored. Censoring is a statistical method that extrapolates the observed trends in seed consumption beyond the period of observation. Removal rates were compared by likelihood ratio tests (Pyke \& Thompson, 1986) in which the course of seed removal was fitted by an exponential function, which is characteristic of a constant removal rate, and a Weibull function, which is characteristic of a continuous increase or decrease in removal rate (Appendix 3), and the fit tested using $\chi^{2}$-tests. The appropriate likelihood test (exponential or Weibull) was selected based on a comparison of the residual deviance and the explanatory power of the models. The structure of the models was checked following Crawley (1993, p. 340), using error-checking plots for censored exponential and Weibull data on age at death (see Aitkin et al., 1989). The mean time to seed removal (consumption time, $\mathrm{CT}_{50}$ ) was calculated as the time to when $50 \%$ of the seeds were removed. To determine the relationships between seed preference and seed size in $P$. rufipes and $H$. affinis, the mean removal rates of the different seeds $\left(\mathrm{CT}_{50}\right)$ were response variables, the species of carabid factors, and natural logarithms of seed weight covariates. The linear and quadratic term of seed weight were used to test whether the relationship had a parabolic shape. The calculations were made using the general linear model in the commercial statistical package GLIM $^{\circledR}$ v. 4 (Francis et al., 1994). The aim of each analysis was to determine the minimal adequate model. In this model, all parameters were significantly $(\mathrm{p}<0.05)$ different from zero and from one another. This was achieved by a step-wise process of model simplification, beginning with the maximal model (containing all factors, interactions and covariates that might be of interest), then all nonsignificant terms are eliminated (using deletion tests from the maximal model) and significant terms retained.

In field experiments the preferences were evaluated using the difference in consumption of seed of particular species exposed simultaneously in a crop (see below).

Seed consumption. In laboratory experiments seed consumption was expressed as number of seeds removed. individual (or unit body mass $)^{-1}$. day ${ }^{-1}$. Regressions $\left(y=b_{0}+b_{1} x\right)$ and Pearson correlation coefficients were calculated using carabid body mass as an explanatory variable and seed consumption as a response variable. Coefficients of determination $\left(\mathrm{R}^{2}\right)$ were calculated to determine the proportion of variance explained by a given relationship.

In field experiments seed consumption was expressed as number of seeds eaten day ${ }^{-1}$ tray $^{-1}$. Average consumption of a particular kind of seed was the arithmetic mean $( \pm \mathrm{SE})$ of the daily consumptions in the different cages. Carabid activity density was the number of individuals trap ${ }^{-1} \mathrm{day}^{-1}$. In experiments establishing the seasonal variation in seed consumption, differences in seed removal rate were related to the seed species or position of the seed within the crop (cage). The significance of these differences was tested using one-way ANOVA, with seed or cage as a factor and average seed consumption as the response variable. The combined effects of cage location and seed were tested in 2000 in crops where seed was placed on sev- 
TABLE 2. The consumption of $C$. arvense and C. bursa-pastoris seeds by carabids in no choice experiments. The table indicates the body mass (Mass, $\mathrm{mg}$ ), number of individuals tested $(\mathrm{N})$, mean and SE of the seed consumption during the 3 day experiment, and daily seed consumption $\left(\mathrm{C}, \mathrm{mg}\right.$ seed. $\mathrm{mg}$ body mass $^{-1}$. day ${ }^{-1}$ ) of each carabid.

\begin{tabular}{|c|c|c|c|c|c|c|c|c|c|}
\hline \multirow{2}{*}{$\begin{array}{l}\text { Species } \\
\text { Name }\end{array}$} & \multirow[b]{2}{*}{ Mass } & \multicolumn{4}{|c|}{ C. arvense } & \multicolumn{4}{|c|}{ C. bursa-pastoris } \\
\hline & & $\mathrm{N}$ & Mean & $\mathrm{SE}$ & $\mathrm{C}$ & $\mathrm{N}$ & Mean & $\mathrm{SE}$ & $\mathrm{C}$ \\
\hline Amara aenea & 6.0 & 6 & 9.7 & 2.3 & 0.423 & 6 & 52.7 & 5.4 & 0.662 \\
\hline Amara aulica & 22.8 & 5 & 27.4 & 8.7 & 0.315 & 3 & 2.0 & 0.8 & 0.007 \\
\hline Amara consularis & 7.8 & 3 & 2.0 & 1.6 & 0.067 & 3 & 0.3 & 0.3 & 0.003 \\
\hline Amara familiaris & 4.0 & 6 & 0.8 & 0.4 & 0.055 & 6 & 24.2 & 3.1 & 0.460 \\
\hline Amara littorea & 6.4 & 6 & 11.0 & 2.1 & 0.449 & 6 & 69.0 & 4.2 & 0.809 \\
\hline Amara ovata & 9.7 & 6 & 11.0 & 2.1 & 0.299 & 5 & 37.0 & 9.6 & 0.288 \\
\hline Amara similata & 8.8 & 6 & 6 & 2.1 & 0.376 & 5 & 85.2 & 1.5 & 0.725 \\
\hline Anchomenus dorsalis & 4.6 & 3 & 1.7 & 1.4 & 0.094 & 3 & 0.0 & 0.0 & 0.000 \\
\hline Anisodactylus signatus & 22.8 & 1 & 40.0 & 0.0 & 0.459 & - & - & - & - \\
\hline Calathus ambiguus & 13.4 & 6 & 0.5 & 0.2 & 0.010 & 6 & 36.8 & 7.9 & 0.207 \\
\hline Calathus fuscipes & 19.2 & 9 & 0.3 & 0.3 & 0.005 & 9 & 0.1 & 0.1 & 0.000 \\
\hline Dolichus halensis & 42.2 & 1 & 1.0 & 0.0 & 0.006 & 1 & 2.0 & 0.0 & 0.004 \\
\hline Harpalus affinis & 13.4 & 5 & 27.0 & 3.9 & 0.528 & 5 & 40.4 & 1.4 & 0.227 \\
\hline Harpalus atratus & 11.4 & 1 & 6.0 & 0.0 & 0.138 & 1 & 0.0 & 0.0 & 0.000 \\
\hline Harpalus distinguendus & 11.7 & 6 & 14.8 & 1.0 & 0.331 & 6 & 42.2 & 9.2 & 0.270 \\
\hline Harpalus signaticornis & 4.8 & 6 & 8.2 & 3.2 & 0.445 & 6 & 27.3 & 4.8 & 0.427 \\
\hline Harpalus tardus & 11.7 & 6 & 15.2 & 1.6 & 0.338 & 5 & 11.0 & 5.2 & 0.070 \\
\hline Ophonus azureus & 6.6 & 8 & 3.3 & 0.8 & 0.128 & 6 & 9.5 & 3.6 & 0.108 \\
\hline Poecilus cupreus & 21.0 & 6 & 6.8 & 2.2 & 0.085 & 4 & 1.5 & 0.6 & 0.005 \\
\hline Pseudoophonus rufipes & 29.6 & 9 & 47.3 & 3.7 & 0.419 & 5 & 5.2 & 2.1 & 0.013 \\
\hline Pterostichus melanarius & 41.5 & 8 & 4.9 & 2.2 & 0.031 & 8 & 0.3 & 0.2 & 0.000 \\
\hline Stomis pumicatus & 4.8 & 4 & 0.0 & 0.0 & 0.000 & 4 & 0.0 & 0.0 & 0.000 \\
\hline Trechus quadristriatus & 1.1 & 6 & 0.0 & 0.0 & 0.000 & 6 & 4.3 & 1.3 & 0.301 \\
\hline
\end{tabular}

eral occasions and the total exposure time was long, wheat stand 1 (exposure: $38 \mathrm{~d}$ ), wheat stand 2 (45 d) and soybean $(34 \mathrm{~d})$. To compensate for temporal variation in seed consumption the analysis of covariance ANCOVA was used, with cage and seed as factors, average seed consumption in each particular period of seed exposure as covariate, and seed removal from particular trays as response variable.

In the field preference experiments the effects of both cage location and seed were determined using two-way ANOVA with cage and seed as factors, and average seed consumption as the response variable. When differences between cages were significant the correlation between carabid activity density and average seed consumption per cage was calculated. All calculations were made using STATISTICA for Windows (StatSoft, 1994).

Comparing preferences. To compare the field preferences established in different experiments, and field and laboratory preferences the results were standardized. Standardized removal rates for the three field experiments were expressed as a fraction of difference between the rejected (the least consumed) and preferred (the most consumed) of the seeds. Standardized consumption rates for the laboratory experiments were calculated using the times required for $50 \%$ of the seed to be removed $\left(\mathrm{CT}_{50}\right)$. $\mathrm{CT}_{50}$ for each kind of seed was calculated as an arithmetic mean for $P$. rufipes and $H$. affinis. The preference for each kind of seed was then expressed as a fraction of the difference between the rejected (longest $\mathrm{CT}_{50}$ ) and the preferred (shortest $\mathrm{CT}_{50}$ ) of the seeds. The standardized preferences, calculated from both seed consumption rate and $\mathrm{CT}_{50}$, then fell between 0 (rejected) and 1 (preferred). Pearson correlation coefficients between (i) standardized preferences for particular seeds in the different field experiments, and (ii) the average standardized preferences obtained in the field experiments and the laboratory were calculated. A crrelation was also calculated for the seed consumption of carabid species established in no choice experiments in this study and those of Goldschmidt \& Toft (1997). The results of both studies were expressed as no. of seeds consumed . individual $^{-1}$. day ${ }^{-1}$.

\section{RESULTS}

\section{Seed consumption in the laboratory}

The consumption of 23 species of carabids offered either seed of $C$. arvense or $C$. bursa-pastoris was recorded (Table 2). Six species (Anchomenus dorsalis, Calathus fuscipes, Dolichus halensis, Poecilus cupreus, Pterostichus melanarius, Stomis pumicatus) were reluctant to eat either of the seeds. Two species (Calathus ambiguus, Trechus quadristriatus) mainly consumed $C$. bursa-pastoris seed. Anisodactylus signatus, of which only 1 individual was available, was offered $C$. arvense seed, but probably would have accepted C. bursa-pastoris seed, and the remaining 14 species accepted both kinds of seed.

The rates of consumption varied with kind of seed and carabid size. The seed of $C$. arvense was universally accepted (Table 2) and the consumption rate of 15 species 


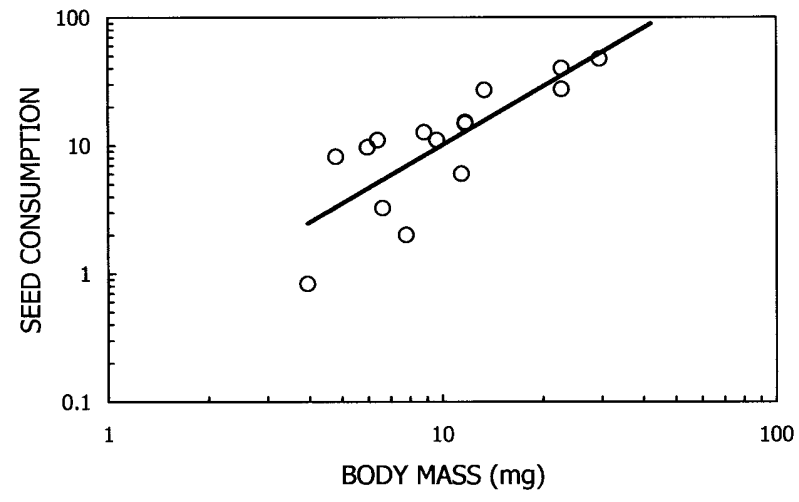

Fig 2. The relationship between consumption, expressed as number of $C$. arvense seeds consumed over a 3 day period, and body mass (mg), for 18 species of carabids (Amara aenea, $A$. aulica, $A$. consularis, $A$. familiaris, $A$. littorea, $A$. ovata, $A$. similata, Anisodactylus signatus, C. ambiguus, C. fuscipes, Harpalus affinis, $H$. atratus, $H$. distinguendus, H. signaticornis, $H$. tardus, Ophonus azureus, Pseudoophonus rufipes, Trechus quadristriatus). Regression: $\mathrm{b}_{0}=-0.5113, \mathrm{~b}_{1}=1.5157, \mathrm{R}^{2}=$ $64.56 \%, \mathrm{df}=13, \mathrm{~F}=23.682, \mathrm{p}<0.001$.

of the tribes Zabrini and Harpalini (seed "consumers") increased with carabid size (Fig. 2). Their average consumption was $0.32 \pm 0.04 \mathrm{mg}$ of seed . mg body mass $^{-1}$. day $^{-1}$. The seeds of C. bursa-pastoris were preferred by small species and rejected by large species of carabid and the consumption of the seed "consumers" was not related
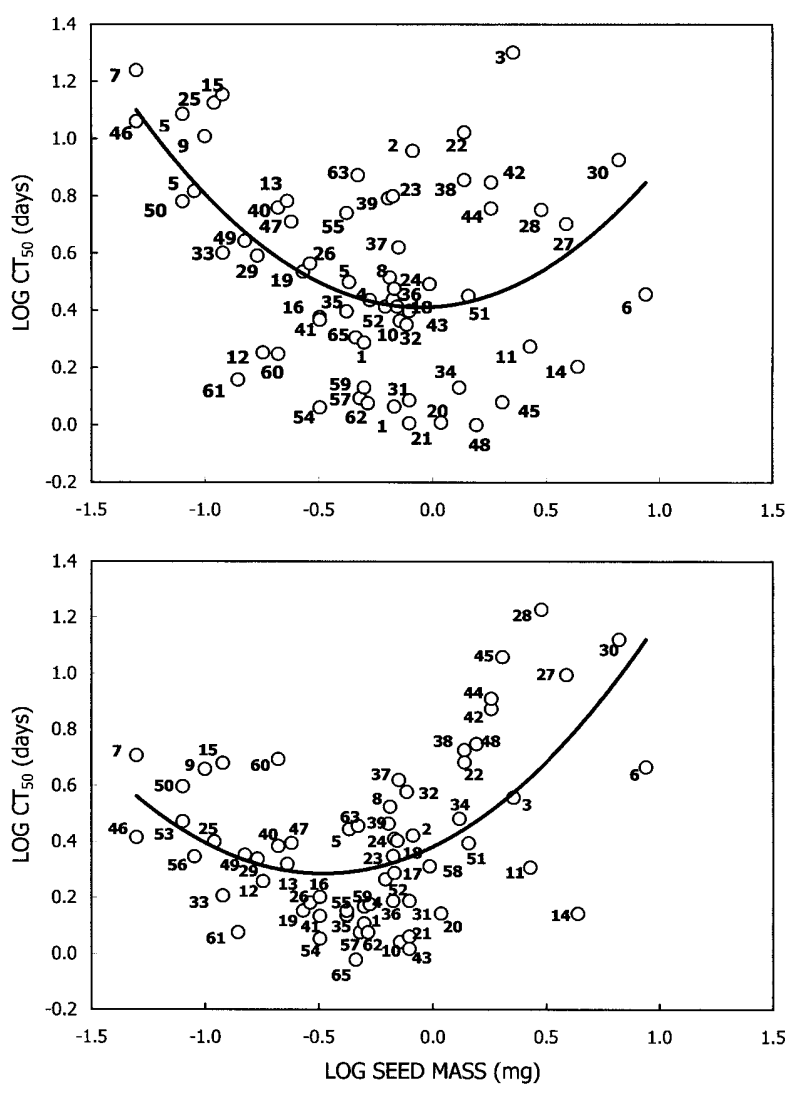

Fig. 4. Regressions of the time to when $50 \%$ of the seed was removed $\left(\mathrm{CT}_{50}\right)$ on seed mass for $P$. rufipes (above) and $H$. affinis (below). Data plotted on log scale. Seed of plants indicated by numbers as listed in Appendix 1.

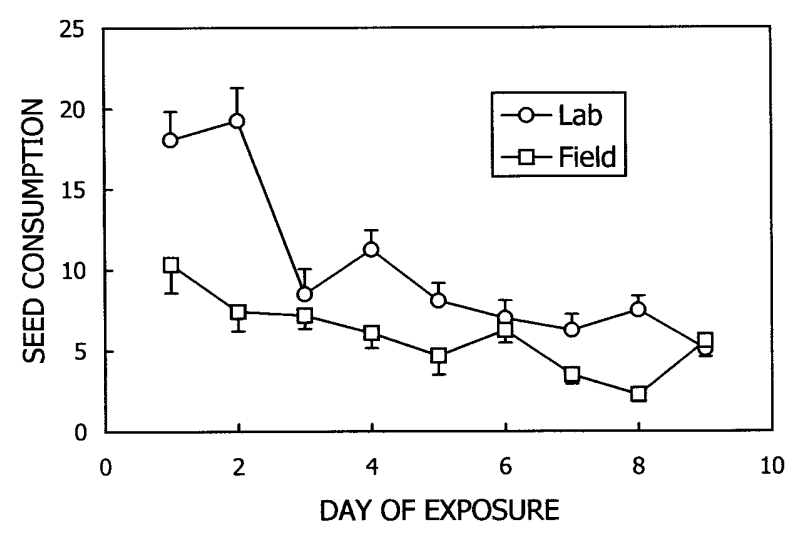

Fig. 3. The average ( $\pm \mathrm{SE})$ rate of consumption of $C$. arvense seeds by individuals of $P$. rufipes kept for 9 days at a constant temperature of $26 \pm 1{ }^{\circ} \mathrm{C}(\mathrm{Lab}, \mathrm{n}=10)$ and under fluctuating temperatures in the field (Field, $\mathrm{n}=10$ ).

to their body size. The average consumption of 14 seed "consumers" was $0.33 \pm 0.04 \mathrm{mg}$ seeds . mg body mass ${ }^{-1}$. day $^{-1}$, i.e. essentially the same as that for $C$. arvense seed $\left(\mathrm{p}_{\mathrm{t}}=0.9131\right)$.

The changes in consumption of $C$. arvense seeds by $P$. rufipes at $26 \pm 1{ }^{\circ} \mathrm{C}$ over a period of 9 days revealed the effect of satiation (Fig. 3). The initial consumption of $18.7 \pm 1.3$ seeds . individual ${ }^{-1}$. day $^{-1}$ (day 1 and 2) decreased to about one third, $6.3 \pm 0.6$ seeds . individual $^{-1}$. day ${ }^{-1}$ on days 8 and 9 . The course of seed consumption was similar in fluctuating (field) temperatures (average at ground level $20.2 \pm 2.6^{\circ} \mathrm{C}$, minimum $11.4 \pm 2.1^{\circ} \mathrm{C}$, maximum $27.8 \pm 4.4^{\circ} \mathrm{C}$ ), where the average consumption was about half that recorded in the laboratory and decreased from $8.9 \pm 1.1$ seeds . individual ${ }^{-1}$. day $^{-1}$ to $3.9 \pm 0.6$ seeds . individual ${ }^{-1}$. day ${ }^{-1}$.

\section{Seed preferences in the laboratory}

Consumption rates (CT50) varied with both seed and carabid species (Fig. 4). To evaluate the differences in the consumption of particular seeds the variation in the preference for the reference species was analysed first. Consumption $\left(\mathrm{CT}_{50}\right)$ of the reference species (the seeds of $C$. arvense in the experiments with $P$. rufipes and those of $C$. bursa-pastoris in those with $H$. affinis) in particular groups of seeds differed significantly (ANOVA for seeds of $C$. arvense: $\chi^{2}=256.29, \mathrm{df}=6, \mathrm{p}=1.45 \mathrm{E}-52$; ANOVA for seeds of C. bursa-pastoris: $\chi^{2}=49.9, \mathrm{df}=6, \mathrm{p}=$ 4.92E-09). This indicated that the preference of both carabid species for the reference seed was affected by what other seeds were offered. The effect of replication within particular seed groups was also significant (seeds of C. arvense: $\chi^{2}=20.26, \mathrm{df}=2, \mathrm{p}=3.99 \mathrm{E}-05$; seeds of C. bursa-pastoris: $\chi^{2}=7.2, \mathrm{df}=2, \mathrm{p}=0.027 \mathrm{E}-52$ ), suggesting an unknown effect other than that attributable to seed choice.

Despite the differences between seed combinations and replicates the results revealed general trends in the seed consumption of both carabid species. Both preferred particular seeds (Fig. 4). A large proportion of the variation in preference was explained by variation in seed size. The relationship between $\mathrm{CT}_{50}$ and seed size was significant 
TABLE 3. Rates of removal of seed (no seeds . day ${ }^{-1}$. tray ${ }^{-1}$ ) of C. bursa-pastoris (13), C. arvense (21), Descurainia sophia (25), Lepidium ruderale (40), Sisymbrium loeselii (53) and Taraxacum officinale (57) placed in a fallow field (FAL), and in stands of maize (MAI), millet (MIL), winter rape (RAP), soybean (SOY) and winter wheat (WHT, WH1, WH2). Mean for each species in a crop and the average for all species in a crop (MEAN). N - number of periods (duration 3-20 days) during which seeds were exposed in each crop; CAG - number of cages per crop; STA - day when seeds were placed in a crop; DUR - total number of days for which the seeds were exposed in each crop.

\begin{tabular}{lccccccccccc}
\hline CROP & N & CAG & STA & DUR & $(13)$ & $(21)$ & $(25)$ & $(40)$ & $(53)$ & $(57)$ & MEAN \\
\hline 1999 & & & & & & & & & & & \\
FAL & 1 & 6 & $19 / 7$ & 10 & 0.10 & 0.20 & 0.00 & 0.00 & 0.30 & 0.00 & 0.10 \\
MIL & 2 & 2 & $26 / 7$ & 23 & $0.15 \pm 0.04$ & $1.30 \pm 0.71$ & $0.30 \pm 0.14$ & $0.10 \pm 0.00$ & $0.30 \pm 0.21$ & $0.70 \pm 0.49$ & $0.48 \pm 0.10$ \\
MAI & 1 & 6 & $26 / 7$ & 9 & 0.00 & 0.30 & 0.10 & 0.00 & 0.00 & 0.60 & 0.17 \\
WHT & 3 & 6 & $22 / 6$ & 24 & $0.63 \pm 0.26$ & $0.17 \pm 0.10$ & $0.73 \pm 0.33$ & $0.53 \pm 0.24$ & $1.17 \pm 0.69$ & $0.13 \pm 0.11$ & $0.56 \pm 0.08$ \\
RAP & 2 & 6 & $22 / 6$ & 14 & $0.95 \pm 0.04$ & $2.45 \pm 0.67$ & $0.90 \pm 0.14$ & $1.40 \pm 0.64$ & $2.10 \pm 0.28$ & $1.05 \pm 0.53$ & $1.48 \pm 0.10$ \\
2000 & & & & & & & & & & & \\
RAP & 4 & 4 & $2 / 6$ & 24 & $0.55 \pm 0.16$ & $1.33 \pm 0.11$ & $0.73 \pm 0.24$ & $0.38 \pm 0.13$ & $0.48 \pm 0.18$ & $0.73 \pm 0.11$ & $0.70 \pm 0.02$ \\
SOY & 12 & 4,8 & $18 / 7$ & 66 & $2.42 \pm 0.47$ & $2.62 \pm 0.43$ & $2.63 \pm 0.62$ & $2.23 \pm 0.46$ & $3.01 \pm 0.52$ & $1.33 \pm 0.21$ & $2.37 \pm 0.05$ \\
WH1 & 6 & 4,8 & $18 / 4$ & 59 & $2.62 \pm 0.91$ & $2.28 \pm 0.53$ & $2.50 \pm 0.84$ & $2.70 \pm 0.95$ & $2.45 \pm 0.85$ & $1.45 \pm 0.27$ & $2.33 \pm 0.10$ \\
WH2 & 10 & 4 & $2 / 6$ & 49 & $3.44 \pm 0.79$ & $4.56 \pm 0.68$ & $3.08 \pm 0.61$ & $2.97 \pm 0.54$ & $3.21 \pm 0.65$ & $3.99 \pm 0.70$ & $3.54 \pm 0.03$ \\
\hline
\end{tabular}

for seed series $\mathrm{i}\left(\mathrm{R}^{2}=39.4 \%, \mathrm{p}<0.05\right)$, iv $\left(\mathrm{R}^{2}=50.4 \%\right.$, $\mathrm{p}$ $<0.005$ ) and vi $\mathrm{R}^{2}=58.9 \%, \mathrm{p}<0.005$ ), which contained seeds of contrasting size, and for the pooled data $\left(\mathrm{R}^{2}=31.0, \mathrm{p}<0.001\right)$. The preferences varied with the size of the carabid, and the interactions between consumption rates and carabid species in individual groups were highly significant $(\mathrm{p}<0.001$, $\mathrm{df}=9$ ). P. rufipes readily consumed medium sized seeds but was more reluctant to eat the smaller and larger seeds, while $H$. affinis preferred smaller seeds than $P$. rufipes (Fig. 4). The calculated preferred seed size was $1.00 \mathrm{mg}$ for $P$. rufipes and $0.32 \mathrm{mg}$ for $H$. affinis. The differences in seed size explained a significant proportion of the variance in the seed consumption of both $P$. rufipes $\left(\mathrm{R}^{2}=24.88 \%\right)$ and $H$. affinis $\left(\mathrm{R}^{2}=33.09 \%\right)$.

TABLE 4. The effect of the position in a crop of the cages containing the seed and kind of seed (species) on the rate of seed removal. ANCOVA - model: see Material and methods. Period of exposure of seed in 2000 in winter wheat stand 1 (April 18-May 26), winter wheat stand 2 (June 2-July 28), soybean (Aug. 8-Oct. 11).

\begin{tabular}{|c|c|c|c|c|c|c|}
\hline & \multicolumn{2}{|c|}{ Effect } & \multicolumn{2}{|c|}{ Error } & \multirow[b]{2}{*}{$\mathrm{F}$} & \multirow[b]{2}{*}{$\mathrm{p}$} \\
\hline & $\mathrm{df}$ & MS & $\mathrm{df}$ & MS & & \\
\hline \multicolumn{7}{|l|}{ Wheat stand 1} \\
\hline cage & 7 & 3.604 & 95 & 0.751 & 4.799 & 0.0001 \\
\hline species & 5 & 0.961 & 95 & 0.751 & 1.280 & 0.2791 \\
\hline cage $\times$ species & 35 & 0.272 & 95 & 0.751 & 0.362 & 0.9995 \\
\hline \multicolumn{7}{|l|}{ Wheat stand 2} \\
\hline cage & 3 & 20.838 & 215 & 6.414 & 3.249 & 0.0228 \\
\hline species & 5 & 15.246 & 215 & 6.414 & 2.377 & 0.0399 \\
\hline cage $\times$ species & 15 & 1.684 & 215 & 6.414 & 0.263 & 0.9977 \\
\hline \multicolumn{7}{|l|}{ Soybean } \\
\hline cage & 7 & 8.233 & 431 & 2.823 & 2.917 & 0.0054 \\
\hline species & 5 & 22.873 & 431 & 2.823 & 8.103 & 0.0000 \\
\hline cage $\times$ species & 35 & 1.684 & 431 & 2.823 & 0.597 & 0.9685 \\
\hline
\end{tabular}

\section{Seed consumption in the field}

In the field the rates of removal of C. bursa-pastoris, $C$. arvense, $D$. sophia, L. ruderale, $S$. loeselii and $T$. officinale seed from the ground under different crops (Table 3 ) varied with season, crop, cage location within a crop and seed. There was a marked seasonal variation in the overall rate of seed removal (Fig. 5). It was low before Julian day 150 (May 29) and after Julian day 250 (September 6), when the average rate of seed removal was 1.1 \pm 0.2 seeds. day $^{-1}(\mathbf{n}=8$ series of exposed seed samples $)$. Between Julian days 150-250 the average rate of seed removal was significantly $\left(\mathrm{p}_{\mathrm{t}}=0.0011\right)$ greater and more variable $\left(2.5 \pm 0.3\right.$ seeds day $^{-1}$, range $\left.0.01-6.2, \mathrm{n}=31\right)$. During this period there was no significant trend in the rate of seed removal (regression: daily seed removal $=$ -0.001 Julian day $+2.659, \mathrm{R}^{2}=0.6 \%$, N.S.). The annual average rate of seed removal was significantly $\left(\mathrm{p}_{\mathrm{t}}=\right.$ $0.0001)$ greater in 2000 (3.2 \pm 0.4 seeds . day $\left.{ }^{-1}, \mathrm{n}=22\right)$ than in $1999\left(0.6 \pm 0.2\right.$ seeds . day $\left.{ }^{-1}, \mathrm{n}=9\right)$. The traps were placed in different fields in the two years.

Between Julian day 150-250 the average rate of seed removal varied between crops. In 1999 the differences were not tested because the number of cage series $(\mathbf{n}=9)$ and crops $(\mathrm{n}=5)$ was small. In 2000 , there was no significant difference $\left(\mathrm{p}_{\mathrm{t}}=0.2824\right)$ between the average rate of seed removal in wheat $\left(3.1 \pm 0.4\right.$ seeds . day $\left.{ }^{-1}, \mathrm{n}=16\right)$ and soybean crops $(2.4 \pm 0.4, \mathrm{n}=12)$, although in both crops the tests were carried out consecutively. The differences in the rate of seed removal in winter wheat and winter rape crops, where seeds were exposed in parallel, are discussed in the next section.

The seeds of different species were removed at different rates. Since the rates of removal varied between cages of the same series, the importance of both factors was investigated in 2000, using data from 2 stands of winter wheat and 1 stand of soybeans (Table 4). The differences between the rates of removal of different seeds were significant in two of the three cases analysed but not in "wheat stand 1", where seed removal rates were low. 


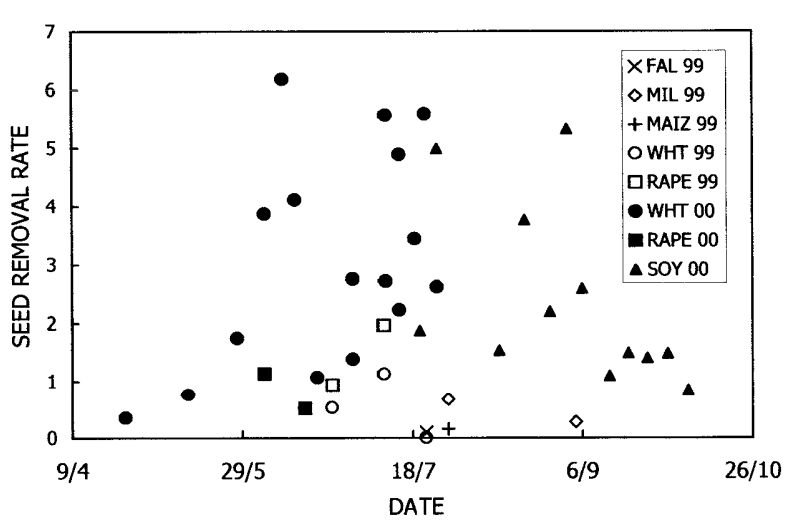

Fig. 5. The average rate of seed removal (seeds . day ${ }^{-1} \cdot \operatorname{tray}^{-1}$ ) from field cages containing seed of six herbaceous species of plant, placed in different crops (MAIZ - maize; MIL - millet; RAPE - winter rape; SOY - soybean; WHT - winter wheat) and a fallow field (FAL), in 1999 (99) and 2000 (00). Each point represents a mean value for a series of cages exposed for a period of 3-20 days. On the abscissa the points are placed in the middle of the exposure period.

Location of a cage within a field significantly affected seed removal rates in all cases. There were thus significant differences in rates of seed removal between microsites within crops.

\section{Factors affecting seed consumption}

The activity density of seed eating carabids varied with season and crop, but $P$. rufipes and $H$. affinis were always dominant (Table 5). A significant relationship between the activity density of the seed eating carabids and the average rate of seed removal (Fig. 6) was established in a soybean stand where carabid activity density declined with the onset of autumn (Fig. 5). In other crops the numbers of cages and/or variation in carabid activity density were too small to reveal a significant relationship.

Differences in seed removal rates paralleling to the availability of naturally occurring seed were established between June 2-26, 2000, in adjacent winter rape and winter wheat stands (Table 6). The distance between cages in both crops was ca. $12 \mathrm{~m}$. The rate of seed removal in the wheat stand $\left(3.8 \pm 0.5\right.$ seeds . day $\left.{ }^{-1}\right)$ was 5.5 times greater than in the rape stand $(0.7 \pm 0.1$ seeds . day $\left.^{-1}\right)$. The difference was associated with the species of weeds that produced seed at this time (C. bursa-pastoris, Lamium amplexicaule, $S$. media, Veronica persica, Viola
TABle 5. Carabid activity density (individuals . $\operatorname{trap}^{-1} \cdot \mathrm{day}^{-1}$ ) at the time seed was placed out in the field and the seed preference experiments PRF1 - PRF3 were done in the field. Consumers: Activity density of all seed eating species $(A$. aenea, $A$. aulica, A. consularis, A. familiaris, A. littorea, A. ovata, A. similata, A. signatus $C$. ambiguus, $H$. affinis, $H$. atratus, $H$. distinguendus, $H$. signaticornis, $H$. tardus, $O$. azureus, $P$. rufipes, T. quadristriatus) and the activity and percentage of the consumers made up of $P$. rufipes and $H$. affinis. Non-consumers: Activity density of species not eating seeds (A. meridianus, $A$. dorsalis, B. lampros, B. obtusum, B. explodens, C. fuscipes, $C$. cancellatus, C. granulatus, L. ferrugineus, L. pilicornis, $M$. minutulus, $N$. pallustris, $P$. cupreus, $P$. melanarius, $S$. pumica$t u s$ ). Date of exposure, duration and number of traps (identical to number of cages used for seed exposure) - see Table 3 .

\begin{tabular}{llllll}
\hline & \multicolumn{4}{c}{ Consumers } & \multirow{2}{*}{$\begin{array}{c}\text { Non- } \\
\text { consumers }\end{array}$} \\
\cline { 2 - 4 } \cline { 3 - 4 } & & \multicolumn{3}{c}{ From this } \\
\cline { 2 - 4 } & & P.rufipes & H. affinis & Both \\
\hline FA9 & & & & \\
FAL & 0.84 & $0.18(21 \%)$ & $0.32(38 \%)$ & $0.50(60 \%)$ & 0.65 \\
MIL & 2.45 & $2.3(94 \%)$ & $0.02(1 \%)$ & $2.32(95 \%)$ & 0.38 \\
MAI & 7.76 & $6.87(89 \%)$ & $0.15(2 \%)$ & $7.02(90 \%)$ & 0.79 \\
WHT & 0.89 & $0.82(92 \%)$ & $0.01(1 \%)$ & $0.83(93 \%)$ & 1.24 \\
RAP & 1.18 & $0.58(49 \%)$ & $0.26(22 \%)$ & $0.84(71 \%)$ & 2.58 \\
PRF1 & 2.58 & $1.86(72 \%)$ & $0.25(10 \%)$ & $2.11(82 \%)$ & 1.7 \\
PRF2 & 4.4 & $4.33(98 \%)$ & $0.01(0 \%)$ & $4.34(99 \%)$ & 0.48 \\
2000 & & & & & \\
RAP & 3.66 & $0.31(8 \%)$ & $0.36(10 \%)$ & $0.67(18 \%)$ & 5.11 \\
SOY & 1.47 & $1.22(83 \%)$ & $0.02(1 \%)$ & $1.24(84 \%)$ & 0.53 \\
WH1 & 0.58 & $0.28(48 \%)$ & $0.04(7 \%)$ & $0.32(55 \%)$ & 0.98 \\
WH2 & 0.76 & $0.61(80 \%)$ & $0.08(11 \%)$ & $0.69(91 \%)$ & 0.8 \\
PRF3 & 1.2 & $0.67(56 \%)$ & $0.00(0 \%)$ & $0.67(56 \%)$ & 1.1 \\
AVER & 2.31 & $1.67(72 \%)$ & $0.13(6 \%)$ & $1.80(78 \%)$ & 1.36 \\
\hline
\end{tabular}

arvensis), which were present in winter rape but virtually absent in winter wheat. The seed eating carabids were more abundant in the winter rape than the winter wheat. Despite the high carabid activity density in the winter rape stand the rate of seed removal was lower there than in the wheat stand, probably because the naturally occurring seed in the rape stand satiated the carabids. Differences in weed abundance, carabid activity and seed removal rates were all significant (Table 6).

Although the differences in seed removal were largely associated with crop and season (Table 3), there was also

TABLE 6. The differences in weed density (plants . $\mathrm{m}^{-2}$ ), carabid activity density (individuals . trap ${ }^{-1}$. day ${ }^{-1}$ ) and seed removal rate (seeds . day ${ }^{-1}$ ) in rape and wheat stands, and the significance of the differences (one-way ANOVA).

\begin{tabular}{|c|c|c|c|c|c|c|c|c|}
\hline & \multicolumn{2}{|c|}{ CROP } & \multicolumn{6}{|c|}{ ANOVA } \\
\hline & \multirow[t]{2}{*}{ Rape } & \multirow[t]{2}{*}{ Wheat } & \multicolumn{2}{|c|}{ Effect } & \multicolumn{2}{|c|}{ Error } & \multirow[b]{2}{*}{$\mathrm{F}$} & \multirow[b]{2}{*}{$\mathrm{p}$} \\
\hline & & & $\mathrm{df}$ & MS & df & MS & & \\
\hline WEED PRESENCE & $92.9 \pm 14.7$ & $0.0 \pm 0.0$ & 1 & 44613 & 25 & 423.29 & 105.4 & $2 \mathrm{E}-10$ \\
\hline CARABID ACTIVITYa & $3.75 \pm 0.87$ & $0.27 \pm 0.7$ & 1 & 30.255 & 8 & 2.3958 & 12.63 & 0.0075 \\
\hline SEED CONSUMPTION & $0.71 \pm 0.09$ & $3.81 \pm 0.1$ & 1 & 19.172 & 6 & 2.252 & 8.514 & 0.0267 \\
\hline
\end{tabular}

${ }^{a}$ Rape: Acupalpus meridianus, Amara aenea, A. aulica, A. familiaris, A. littorea, A. similata, Calathus ambiguus, Harpalus affinis, H. atratus, H. distinguendus, H. signaticornis, H. tardus, Ophonus azureus, Pseudoophonus rufipes. Wheat: A. aulica, A. familiaris, A. similata, C. ambiguus, $H$. affinis, $H$. signaticornis, $P$. rufipes. 


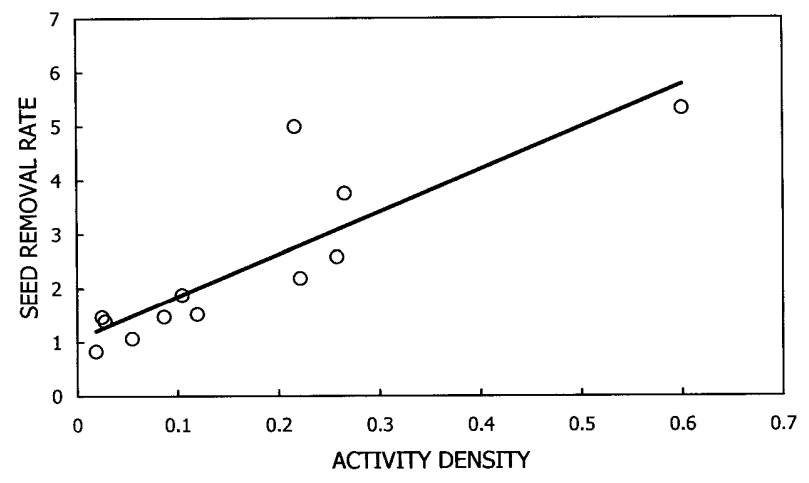

Fig. 6. The relationship between the average rate of seed removal (seeds . day ${ }^{-1} \cdot$ tray $^{-1}$ ) and the average activity density of species of seed eating carabids (individuals . day ${ }^{-1}$. trap $^{-1}$ ) in the soybean crop, July 17 and October $11,2000 . \mathrm{R}^{2}=72.76 \%$, $\mathrm{df}=10, \mathrm{p}<0.001$.

variation in the removal rate of particular seeds. The average rates of removal of particular seeds in different crops in both years were significantly correlated (Table 7).

\section{Seed preferences in the field}

Differences in seed removal in the field were investigated in 3 experiments (Table 8). There were significant differences in the rates of removal of the different seeds in all experiments (Table 9), indicating variation in the preference for particular seeds in the field. The standardized removal rates for the seed of $A$. retroflexus, $C$. album, G. parviflora, L. amplexicaule, M. maritima, $M$. pratense, $S$. media, $T$. arvense and $V$. persica from winter wheat and millet crops in 1999 were not significantly correlated ( $\mathrm{df}=7, \mathrm{R}^{2}=3.09 \%$, N.S.) probably because of differences in the composition of the carabid community. However, the removal rates for particular seeds from millet (1999) and winter wheat stands (2000) were correlated $\left.\left(\mathrm{df}=3, \mathrm{R}^{2}=87.24 \%, \mathrm{p}<0.05\right)\right)$ (Fig. 7).

\section{Comparison of preferences obtained in the laboratory and field}

The preferences for the seed of particular herbaceous species obtained in the field and laboratory were compared using the standardized data. They were significantly correlated (Fig. 8). The scatter in the data increased with increasing preference. The increase in scatter means that the seed of species rejected in the laboratory were

TABLE 7. The correlation $\left(\mathrm{R}^{2}\right)$ between the removal rates of particular seeds from trays exposed in 1999 and 2000 in different crops. All correlations are significant at $p<0.05$ (critical value: $0.095, \mathrm{df}=39$ ). Plant species indicated by numbers as listed in Appendix 1.

\begin{tabular}{|c|c|c|c|c|c|c|}
\hline & 13 & 21 & 25 & 40 & 53 & 57 \\
\hline 13 C. bursa-pastoris & 1.000 & & & & & \\
\hline 21 C. arvense & 0.315 & 1.000 & & & & \\
\hline 25 D. sophia & 0.854 & 0.274 & 1.000 & & & \\
\hline 40 L. ruderale & 0.865 & 0.320 & 0.912 & 1.000 & & \\
\hline $53 S$. loeselii & 0.860 & 0.232 & 0.868 & 0.809 & 1.000 & \\
\hline 57 T. officinale & 0.187 & 0.647 & 0.157 & 0.222 & 0.097 & 1.000 \\
\hline
\end{tabular}

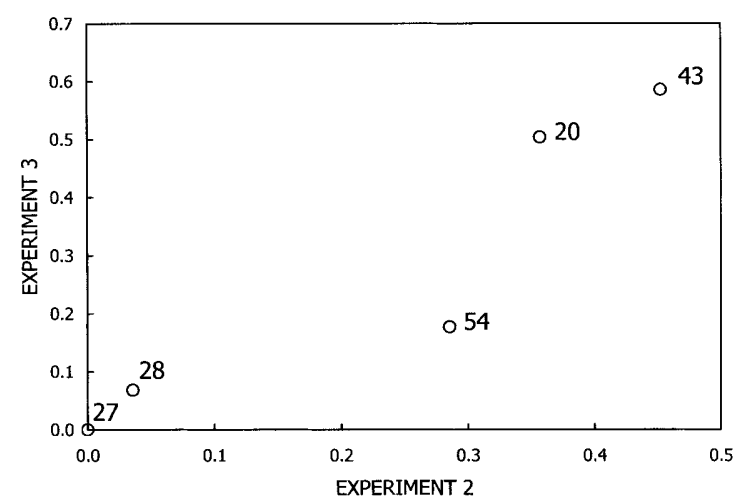

Fig. 7. The plot of the standardized seed removal rates for five herbaceous species common to field preference experiment 2 (millet, August 5-18, 1999) and 3 (winter wheat July 30-August 10,2000). Seed species indicated by numbers listed in Appendix 1: 20 - Cichorium intybus; 27 - Fallopia convolvulus; 28 - Fumaria officinalis; 43 - Melandrium pratense; 54 Sonchus arvensis. $\mathrm{R}^{2}=87.22 \%, \mathrm{p}<0.05$.

TABLE 8. Average daily consumption (no seed . tray $^{-1}$. day ${ }^{-1}$, mean $\pm \mathrm{SE}$ ) of different seeds in the field preference experiments. Experiment 1: winter wheat July, 14-22, 1999. Experiment 2: millet August 5-18, 1999. Experiment 3: winter wheat, July 30 -August $10,2000$.

\begin{tabular}{llccc}
\hline Species & Experiment 1 & Experiment 2 & Experiment 3 \\
\hline 2 Achillea millefolium & - & $0.06 \pm 0.03$ & - \\
4 Amaranthus retroflexus & $0.13 \pm 0.13$ & $0.97 \pm 0.37$ & - \\
5 Anagalis arvensis & $0.28 \pm 0.12$ & - & - \\
7 Arenaria serpyllifolia & - & $0.17 \pm 0.07$ & - \\
8 Balota nigra & - & $0.22 \pm 0.10$ & - \\
13 Capsella bursa-pastoris & - & $0.06 \pm 0.03$ & - \\
15 Cerastium holosteoides & $0.78 \pm 0.62$ & - & - \\
17 Chelidonium majus & $1.15 \pm 0.48$ & - & - \\
18 Chenopodium album & $1.73 \pm 0.21$ & $0.17 \pm 0.06$ & - \\
20 Cichorium intybus & $0.46 \pm 0.28$ & - & $1.35 \pm 0.39$ \\
21 Cirsium arvense & - & $1.29 \pm 0.23$ & - \\
22 Consolida regalis & - & - & $0.65 \pm 0.08$ \\
23 Crepis biennis & $0.13 \pm 0.08$ & - & - \\
24 Daucus carota & $0.63 \pm 0.21$ & - & - \\
27 Fallopia convolvulus & - & $0.00 \pm 0.00$ & $0.00 \pm 0.00$ \\
28 Fumaria officinalis & - & $0.05 \pm 0.05$ & $0.18 \pm 0.08$ \\
29 Galinsoga parviflora & $0.38 \pm 0.21$ & $0.05 \pm 0.03$ & - \\
30 Galium aparine & $0.05 \pm 0.05$ & - & $0.45 \pm 0.28$ \\
33 Hypericum perforatum & - & $0.11 \pm 0.07$ & - \\
34 Jacea pratensis & - & $0.62 \pm 0.12$ & - \\
35 Lactuca serriola & $1.13 \pm 0.64$ & - & $1.38 \pm 0.39$ \\
36 Lamium amplexicaule & $1.35 \pm 0.28$ & $0.49 \pm 0.19$ & - \\
38 Lapsana communis & $0.00 \pm 0.00$ & - & - \\
39 Leonurus cardiaca & $0.08 \pm 0.03$ & - & - \\
41 Matricaria maritima & $0.13 \pm 0.08$ & $0.11 \pm 0.07$ & - \\
42 Medicago lupulina & $0.05 \pm 0.05$ & - & $0.73 \pm 0.22$ \\
43 Melandrium pratense & $0.33 \pm 0.15$ & $0.58 \pm 0.38$ & $1.56 \pm 0.34$ \\
44 Melilotus officinalis & $0.71 \pm 0.18$ & - & - \\
46 Origanum vulgare & - & $0.12 \pm 0.06$ & - \\
47 Plantago major & $0.75 \pm 0.25$ & - & - \\
48 Polygonum aviculare & - & $0.18 \pm 0.05$ & - \\
50 Potentilla argentea & - & $0.00 \pm 0.00$ & - \\
\hline & & &
\end{tabular}




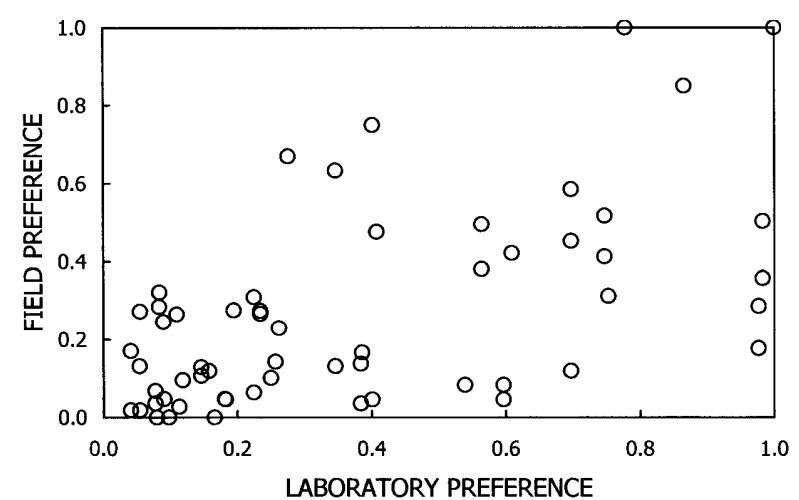

Fig 8 . The relationship between the standardized field preferences and standardized laboratory preferences for the seed of 42 weed species (some species are shown more than once because of their repeated exposure in the field). $\mathrm{R}^{2}=34.85 \%$, $\mathrm{df}=58, \mathrm{p}$ $<0.001$.

also rejected in the field, but the consumption of preferred seed in the field and in the laboratory varied greatly.

\section{DISCUSSION}

Seed removal vs. consumption. The seed removal rates recorded in the laboratory varied. Preferred seeds were consumed shortly after the start of an experiment whereas those of non-preferred species were eaten reluctantly, probably as a consequence of the increasing hunger of the beetles. The carabids removed the seeds from the plasticine, and took them away, often carrying them in their mandibles around the experimental arena for several seconds, before crushing the testa and eating the seed's contents. The inspection of seed remains indicated that all the seeds that were removed were eaten by the large species, $P$. rufipes (body mass $29.6 \mathrm{mg}$ ). The small species, $H$. affinis $(13.4 \mathrm{mg})$, removed but later left uneaten the seeds of some species, e.g. G. aparine. The seed used in this study experienced a long after-ripening period and intact seeds of most species were capable of germinating under laboratory conditions (Martinkova, unpubl.). Seed which was removed from the plasticine but not eaten would thus germinate in the moist soil of the experimental arenas. However, germination was rarely observed, which means that most of the seeds that were removed were eaten.

Causes of variation in seed removal. The trend of increasing consumption with body size was confounded by preferences for particular seeds. The most important character determining the consumption of a particular kind of seed in the multichoice experiment was its mass, which explained $25 \%$ of the variance in seed consump-

TABle 9. The differences (one-way ANOVA) in the removal rate of different seeds in field experiments 1-3 (see Table 8).

\begin{tabular}{lcccccccc}
\hline & \multicolumn{2}{c}{ Effect } & & \multicolumn{2}{c}{ Error } & & \\
\cline { 2 - 3 } & df & MS & & df & MS & F & p \\
\hline Experiment 1 & 23 & 2.354 & & 96 & 0.605 & 3.8922 & $1.38 \mathrm{E}-06$ \\
Experiment 2 & 23 & 0.505 & & 96 & 0.120 & 4.2086 & $3.23 \mathrm{E}-07$ \\
Experiment 3 & 11 & 3.413 & & 48 & 0.320 & 10.6567 & $1.51 \mathrm{E}-09$ \\
\hline
\end{tabular}

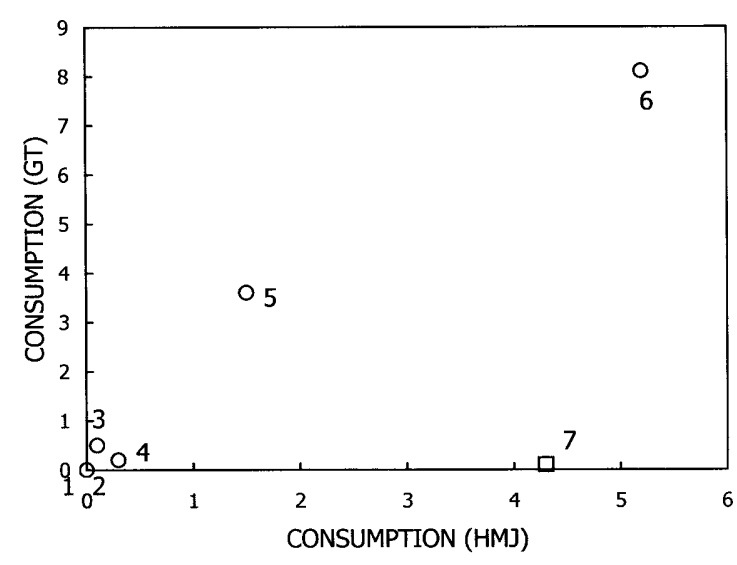

Fig. 9. The relationship between consumption in the laboratory (no. of seeds . individual ${ }^{-1}$. day ${ }^{-1}$ ) of C. bursa-pastoris seed by 7 carabid species common to this study (HMJ) and that of Goldschmidt and Toft (1997) (GT). 1 - A. dorsalis; 2 - S. pumicatus; 3 - C. fuscipes; $4-P$. melanarius; 5 - P. cupreus; $6-P$. rufipes; $7-T$. quadristriatus (this species was omitted when calculating the correlation). $\mathrm{R}^{2}=97.22 \%, \mathrm{p}<0.001$.

tion by $P$. rufipes and $33 \%$ in $H$. affinis. The high residual variation may be due to morphological and/or biochemical differences between seeds, e.g. in the thickness and/or consistency of the seed testa and the hardness of a seed's contents (cotyledons). This is indicated by the difference in the consumption of similarly sized seed. Both $P$. rufipes and $H$. affinis readily accepted seeds of $A$. lappa (seed: $8.72 \mathrm{mg}$ ) and $B$. tripartita $(2.69 \mathrm{mg})$, which are large but apparently have a soft testa and cotyledons, while the seeds of G. aparine (6.64 mg), Fallopia convolvulus $(3.90 \mathrm{mg})$ and Fumaria officinalis $(3.01 \mathrm{mg})$ were rejected.

Comparing laboratory data. Although the consumption of seed by different carabid species was studied previously by several authors (Goldschmidt \& Toft, 1997; Tooley et al., 1999; Lietti et al., 2000) comparison of the consumption rates they recorded is difficult due to differences in the species of seed offered, temperature and pretreatment history of the carabids. Goldschmidt \& Toft (1997) provide data on the consumption of C. bursapastoris seed by 7 of the carabid species used in our study. The seed consumptions they report are similar (Fig. 9), except for T. quadristriatus, which consumed substantially more seed in our study. Both studies revealed similar seed preferences and consumption rates for populations of carabids from different regions of Europe.

Seed consumption by carabids in the field. This study revealed that a high proportion of the small seed of herbaceous plants present on the ground in arable fields in central Europe may be eaten by invertebrates, specifically carabid beetles. We found that several species of carabid eat large quantities of seed of a range of species. Our results thus amplify the results of earlier studies (Introduction) that mostly used a small number of predators and/or kinds of seed. What might be the role of other potential seed predators? Pitfall traps revealed the activity 
density of the arthropod fauna in the vicinity of the cages containing seed. Of the arthropods caught in the pitfall traps only the carabids are likely to eat seed. Ants (Lasius spp.) were scarce and their numbers always made up < $1 \%$ of the catch of adult carabids. Also, during visual inspections and servicing of the pitfall traps and seed cages, few ants were observed, probably because of the distance of the cages from ridges (mostly $>40 \mathrm{~m}$ ). Crickets, typical inhabitants of steppe localities in the Czech Republic, were not present. Some millipeds (Blaniulus spp., Polydesmus spp.) and beetles (Silpha spp.) present in pitfall catches did not eat seed in laboratory experiments (Honek, unpubl.). Slugs will eat the plasticine and the seeds. However, there was no evidence of slug (Deroceras spp.) activity (mucus trails and characteristic scars on plasticine) in our experiments. Carabids were thus the most important invertebrate granivores. The importance of granivory for polyphagous carabids may be greater than previously stated by Thiele (1977), who reported they eat mainly young green vegetation and fruit. This is not surprising since the energy content of seed is greater than that of other plant parts.

It is not possible to decide what proportion of the seeds were removed by carabid adults and larvae, respectively. Larvae (not identified to species) were rare in our pitfall catches. However, pitfall traps may underestimate their densities because of their different size and speed of movement (Adis, 1979). Therefore, their role in seed mortality may be greater than indicated by their activity density. Moreover, experiments of P. Saska (pers. comm.) revealed that most larvae were unable to remove seed from plasticine. The combined adult and larval predation may thus be greater than revealed by our study.

Variation in seed removal in the field. Changes in the composition of carabid community may affect the relative mortality experienced by small and large seed. The preferences for particular seeds changed with carabid body mass. As the composition of carabid communities varied during the course of a season the proportion of the seeds of a particular size that were removed also changed. Thus in 2000, small seed consumers (Amara spp., Harpalus spp., Ophonus spp.) dominated the carabid community until early August. Later on the average size of the seed eating species increased due to a dramatic increase in the activity of $P$. rufipes. Other large seed eaters (Amara aulica, A. signatus) also became active. After midSeptember the activity density of large species decreased and the community of seed eaters was again dominated by small species, particularly $T$. quadristriatus. Carabid communities made up of mainly small species may prefer small seeds, and those composed of large species mainly large seeds.

Seed predation. Our data may be used to estimate seed removal in the field. A minimum estimate is that obtained for the winter rape crop in 2000, where seeds produced by naturally occurring weeds were available in excess and the carabids were satiated. As a consequence, the carabids probably removed the experimental seeds at a similar rate to the naturally occurring seeds. From the area of the trays $\left(6.2 \mathrm{~cm}^{2}\right)$ and the daily removal rates $(0.7$ seeds . tray $^{-1}$ ) the daily removal rate can be calculated and is c. 1150 seeds. $\mathrm{m}^{-2}$. This figure may decrease when the activity density of seed eating carabids decreases: it was rather high in our case, 3.7 individuals . trap ${ }^{-1}$. day $^{-1}$. On the other hand, consumption rates may increase with increase in carabid hunger - as demonstrated for $P$. rufipes. Average seed removal rate, in June-August, over the 2 year period (1999-2000), was 2.5 seeds . tray ${ }^{-1}$. day $^{-1}$. Accepting this estimate of seed predation increases consumption to c. 4000 seeds. $\mathrm{m}^{-2}$. day $^{-1}$. Greater consumption rates may occur in crops where there are few weeds or they are patchily distributed, or they are at the beginning of seed production. This corresponds with the general conclusion that seed consumption is important when seed production is low (Harper, 1977). Average seed consumption did not change substantially between Julian days 150 and 250 . This indicates that the potential pressure of carabids on seed on the ground may be rather constant in a particular year. Seed consumption by carabids decreases the number of seeds of herbaceous plants that enter the soil seed bank and may be an important factor controlling weeds on arable land.

ACKNOWLEDGEMENTS. The work was partly funded from grant no. 521/03/0171 of the Grant Agency of the Czech Republic to A.H. and Z.M. V.J. was supported by MŠMT grant no. J13/98113100004. We thank Prof. A.F.G. Dixon (Norwich, UK) for important comments and language editing, and Mrs. L. Kreslová and Mrs. H. Uhliŕová for excellent technical assistance.

\section{REFERENCES}

ADIS J. 1979: Problems of interpreting arthropod sampling with pitfall traps. Zool. Anz. 202: 177-184.

Aitkin M., Anderson D., Francis B. \& Hinde J. 1989: Statistical Modelling in GLIM. Clarendon Press, Oxford, UK, pp.

ALLEN R.T. 1979: The occurrence and importance of ground beetles in agricultural and surrounding habitats. In: Erwin T.L., Ball G.E., Whitehead D.A. \& Halpern A.S. (eds): Carabid Beetles: Their Evolution, Natural History, and Classification. Junk, The Hague, The Netherlands, pp. 485-505.

ANDERSEN A.N. 1982: Seed removal by ants in the mallee of northwestern Victoria. In: Buckley R.C. (ed.): Ant-Plant Interactions in Australia. Junk, The Hague, The Netherlands, pp. 31-43.

ANDERSEN A.N. \& Asriton D.H. 1985: Rates of seed removal by ants at heath and woodland sites in southeastern Australia. Aust. J. Ecol. 10: 381-390.

Best R.L. \& BEEGLE C.C. 1977: Food preferences of five species of carabids commonly found in Iowa cornfields. Env. Entomol. 6: 9-12.

BRANDMAYR T.Z. 1990: Spermophagous (seed eating) ground beetles: First comparison of the diet and ecology of the Harpaline genera Harpalus and Ophonus (Col.: Carabidae). In: Stork N.E. (ed.): The Role of Ground Beetles in Ecological and Environmental Studies. Intercept, Andover, Hampshire, UK, pp. 307-316.

Brown J.H., ReIChMan O.J. \& Davidson D.W. 1979: Granivory in desert ecosystems. Annu. Rev. Ecol. Syst. 10: 201-227.

Brust G.E. \& House G.J. 1988: Weed seed destruction by arthropods and rodents in low-input soybean agroecosystems. Am. J. Alternative Agric. 3: 19-35. 
BuRakowsKI B. 1967: Biology, ecology and distribution of Amara pseudocommunis Burak. (Coleoptera: Carabidae). Ann. Zool. 24: 486-523.

BurmeIster F. 1939: Biologie, Ökologie und Verbreitung der Europäischen Käfer. I. Band: Adephaga, Caraboidea. Goecke Verlag, Krefeld, Germany, 206 pp.

Cardina J., Norquay H.M., Stinner B.R. \& MCCartney D.A. 1996: Postdispersal predation of velvetleaf (Abutilon theophrasti) seeds. Weed Sci. 44: 534-539.

Carmona D.M., Menalled F.D. \& Landis D.A. 1999: Northern field cricket, Gryllus pennsylvanicus Burmeister (Orthoptera: Gryllidae): laboratory weed seed predation and within-field activity-density. J. Econ. Entomol. 92: 825-829.

Coates-Estrada R. \& Estrada A. 1988: Frugivory and seed dispersal in Cymbopetalum ballionii (Annonaceae) at Los Tuxtlas, Mexico. J. Trop. Biol. 4: 157-172.

Crawley M.J. 1992: Seed predators and plant population dynamics. In: Fenner M. (ed.): Seeds: the Ecology of Regeneration in Plant Communities. CAB International, Wallingford, UK, pp. 159-191.

CRAWLEY M.J. 1993: GLIM for Ecologists. Blackwell, London, UK, $379 \mathrm{pp}$.

Crawley M.J. (ed.) 1997: Plant Ecology, 2nd edn. Blackwell Science, Oxford, UK, $715 \mathrm{pp}$.

Davies M.J. 1953: The contents of the crops of some British carabid beetles. Entomol. Month. Mag. 88: 18-23.

DAwson N. 1965: A comparative study of the ecology of eight species of fenland Carabidae (Coleoptera). J. Anim. Ecol. 34: 299-314.

Dostal J. 1989: New Flora of the CSSR. Academia, Praha, Czech Republic, 1548 pp. [in Czech]

Forbes S.A. 1883: The food relationships of the Carabidae and Coccinellidae. Illinois State Lab. Nat. Hist. Bull. 1: 33-64.

Francis B., Green M. \& Payne C. (eds) 1994: The GLIM System. Release 4 Manual. Clarendon Press, Oxford, UK, 859 pp.

GoldSChMmT H. \& TоFт S. 1997: Variable degrees of granivory and phytophagy in insectivorous carabid beetles. Pedobiologia 41: 521-525.

HARPER J.L. 1977: Population Biology of Plants. Academic Press, London, UK, 892 pp.

Harrison S.K., Regnier E.E., Schmoll J.T. 2003: Postdispersal predation of giant ragweed (Ambrosia trifida) seeds in notillage corn. Weed Sci. 51: 955-964.

HartKe A., Drummond F. A. \& Liebman M. 1998: Seed feeding, seed caching, and burrowing behaviours of Harpalus rufipes DeGeer larvae (Coleoptera: Carabidae) in the Maine potato agroecosystem. Biol. Control 13: 91-100.

HenGeveld R. 1980a: Qualitative and quantitative aspects of the food of ground beetles (Coleoptera: Carabidae): a review. Neth. J. Zool. 30: 555-563.

Hengeveld R. 1980b: Polyphagy, oligophagy and food specialization in ground beetles (Coleoptera: Carabidae). Neth. J. Zool. 30: 564-584.

Holland J.M. \& LufF M.L. 2000: The effects of agricultural practices on Carabidae in temperate ecosystems. Integr. Pest Manag. Rev. 5: 109-129.

Hölldobler B. \& Wilson E.O. 1990: The Ants. Springer, Berlin, Germany, $732 \mathrm{pp}$.

HONEK A. \& JAROSIK V. 2000: The role of crop density, seed and aphid presence in diversification of field communities of Carabidae (Coleoptera). Eur. J. Entomol. 97: 517-525.

HoneK A. \& MartinKova Z. 2001: Aggregation of ground beetles (Carabidae, Coleoptera) on winter rape seeds dispersed on the ground. Plant Prot. Sci. 37: 97-102.
Hulme P.E. 1998: Post-dispersal seed predation and seed bank persistence. Seed Sci. Res. 8: 513-519.

HURKa K. 1996: Carabidae of the Czech and Slovak Republics. Kabourek, Zlín, Czech Republic, 565 pp.

HurKa K. 1998: Larval taxonomy, development and diet of Amara (Amara) famelica, A. (A.) littorea and A. (A.) proxima (Coleoptera: Carabidae: Amarina). Acta Soc. Zool. Bohem. 62: 105-113.

JAROSIK V. 1989: Mass vs. length relationship for carabid beetles (Col., Carabidae). Pedobiologia, 33: 87-90.

Jornson N.E. \& CAmeron R.S. 1969: Phytophagous ground beetles. Ann. Entomol. Soc. Am. 62: 909-914.

JøRGENSEN H.B. \& TofT S. 1997a: Food preference, diet dependent fecundity and larval development in Harpalus rufipes (Coleoptera: Carabidae). Pedobiologia 41: 307-315.

JøRGENSEN H. B. \& TOFT S. 1997b: Role of granivory and insectivory in the life cycle of the carabid beetle Amara similata. Ecol. Entomol. 22: 7-15.

Kinnunen H. \& Trainen J. 1999: Carabid distribution in a farmland mosaic: the effect of patch type and location. Ann. Zool. Fenn. 36: 149-158.

KIRK V.M. 1972: Seed-caching by larvae of two ground beetles Harpalus pensylvanicus and H. erraticus. Ann. Entomol. Soc. Am. 65: 1426-1428.

KJelisson G. 1985: Seed fate in a population of Carex pilulifera L. II. Seed predation and its consequences for dispersal and the seedbank. Oecologia 67: 424-429.

KоктA C. 1988: Beziehungen zwischen der Verunkrautung und phytophagen Laufkäfern der Gattung Amara. Mitt. Biol. Bundesanst. Land-Forstwirt. Berlin-Dahlem 247: 139-145.

Kromp B. 1990: Carabid beetles (Coleoptera, Carabidae) as bioindicators in biological and conventional farming in Austrian potato fields. Biol. Fertil. Soils 9: 182-187.

KROMP B. 1999: Carabid beetles in sustainable agriculture: a review on pest control efficacy, cultivation impacts and enhancement. Agric. Ecosyst. Environ. 74: 187-228.

Lietti M., Montero G., Faccini D. \& Nisensohn L. 2000: Evaluacion del consumo de semillas de malezas por Notiobia (Anisotarsus) cupripennis (Germ.) (Coleoptera: Carabidae). Pesq. Agropec. Brasil. 35: 331-340.

Lindroth C.H. 1949: Die Fenoskandischen Carabidae III Allgemeiner Teil. Kgl. Vetenskaps Vitterhetssamhällets Handl F6, Ser. B 4., $911 \mathrm{pp}$.

LoudDA S.M. 1989: Predation in the dynamics of seed regeneration. In: Leck M.A., Parker V.T. \& Simpson R.L. (eds): Ecology of Soil Seed Banks. Academic Press, San Diego, USA, pp. 25-51.

Louda S.M., Potvin M.A. \& Collinge S.K. 1990: Predispersal seed predation, postdispersal seed predation and competition in the recruitment of seedlings of a native thistle in Sandhills prairie. Am. Midl. Nat. 124: 105-113.

Löver G. \& SzentKIRALYI F. 1984: Carabids climbing maize plants. Z. Angew. Entomol. 97: 107-110.

LÖVEI G. L. \& SUNDERLAND K.D. 1996: Ecology and behavior of ground beetles (Coleoptera: Carabidae). Annu. Rev. Entomol. 41: 231-256, 1996.

LufF M.L. 1980: The biology of the ground beetle Harpalus rufipes in a strawberry field in Northumberland. Ann. Appl. Biol. 94: 153-164.

LuFF M.L. 1987: Biology of polyphagous ground beetles in agriculture. Agric. Zool. Rev. 2: 237-278.

Luka H., Pfiffner L. \& Wyss E. 1998: Amara ovata und A. similata (Coleoptera, Carabidae), zwei phytophage Laufkäferarten in Rapsfeldern. Mitt. Schweiz. Entomol. Ges. 71: 125-131. 
Lund R.D. \& TuRPIN F.T. 1977: Carabid damage to weed seeds found in Indiana cornfields. Env. Entomol. 6: 695-698.

Manley G.V. 1971: A seed-cacheing carabid (Coleoptera). Ann. Entomol. Soc. Am. 64: 1474-1475.

MANLEY G.V. 1992: Observations on Harpalus pensylvanicus (Coleoptera: Carabidae) in Michigan seed corn fields. News Michigan Entomol. Soc. 37: 1-2.

Marino P.C., Gross K.L. \& Landis D.A. 1997: Weed seed loss due to predation in Michigan maize fields. Agric. Ecosyst. Environ. 66: 189-196.

Maron J.L. \& Gardner S.N. 2000: Consumer pressure, seed versus safe-site limitation, and plant population dynamics. Oecologia 124: 260-269.

Marone L., Horno M.E. \& Del Solar R.G. 2000: Postdispersal fate of seeds in Monte desert of Argentina: patterns of germination in successive wet and dry years. J. Ecol. 88: 940-949.

Martinkova Z., Honek A. \& Štolcová J. 1997: The incidence of primary seed dormancy in weed species of the Czech Republic. Ochrana Rostlin 33: 265-279.

Menalled F.D., Marino P.C., Renner K.A. \& Landis D.A 2000: Post-dispersal weed seed predation in Michigan crop fields as a function of agricultural landscape structure. Agric. Ecosyst. Environ. 77: 193-202.

Price M.V. \& JENKINS S.H. 1986: Rodents as seed consumers and dispersers. In: Murray D.R. (ed.): Seed Dispersal. Academic Press, Sydney, Australia, pp. 191-235.

Pyke D.A. \& Thompson J.N. 1986: Statistical analysis of survival and removal rate experiments. Ecology 67: 240-245.

RAMrREZ N. \& ARroyo M.K. 1987: Variacion espacial y temporal en la depredacion de semillas de Copaifera pubiflora Benth. (Leguminosae: Caesalpinioideae) en Venezuela. Biotropica 19: 32-39.

READER R.J. 1991: Control of seedling emergence by ground cover: a potential mechanism involving seed predation. Can. J. Bot. 69: 2084-2087.

ReAder R.J. \& BeIsner B.E. 1991: Species-dependent effects of seed predation and ground cover on seedling emergence of old-field forbs. Am. Midl. Nat. 126: 279-286.

Risch S.J. \& CARROLL C.R. 1986: Effects of seed predation by a tropical ant on competition among weeds. Ecology 67: 1319-1327.

SASKa P. \& JAROSIK V. 2001: Laboratory study of larval food requirements in nine species of Amara (Coleoptera: Carabidae). Plant Protect. Sci. 37: 103-110.

Schremmer F. 1960: Beitrag zur Biologie von Ditomus clypeatus Rossi, eines körnersammelnder Carabiden. Z. Arbeitsgem. Öterr. Entomol. 3: 140-146.

Skumravy V. 1959: Die Nahrung der Feldcarabiden. Acta Soc. Entomol. Čechoslov. 56: 1-18.

SocHA R. 1993: Pyrrhocoris apterus (Heteroptera) - an experimental model species: a review. Eur. J. Entomol. 90: 241-286.

STATSOFT 1994: Statistica for Windows (Volume I): General Conventions and Statistics I. StatSoft Inc., Tulsa, USA, 692 pp.

Swanton C.J., Griffiths J.T., Cromar H.E. \& Booth B.D. 1999 Pre- and post-dispersal seed predation and its implications to agriculture. Proc. Int. Conf. Brighton UK 15-18 November 1999, Vol. 3. British Crop Protection Council, Farnham, UK, pp. 829-834.

ThIELE H.U. 1977: Carabid Beetles in Their Environments. Springer, Berlin, Germany, 369 pp.

Thomas C.F.G., Parkinson L., Grifitims G.J.K., Fernandez Garcia A. \& Marshall E.J.P. 2001: Aggregation and tem- poral stability of carabid beetle distributions in field and hedgerow habitats. J. Appl. Ecol. 38: 100-116.

ToFt S. \& BILde T. 2002: Carabid diets and food value. In: Holland J.M. (ed.): The Agroecology of Carabid Beetles. Intercept, Andover, pp. 81-110.

TOOLEY J. \& BRUST G.E. 2002: Weed seed predation by carabid beetles. In: Holland J.M. (ed.): The Agroecology of Carabid Beetles. Intercept, Andover, pp. 215-229.

Tooley J.A., Froud-Williams R.J., Boatman N.D. \& Holland J.M. 1999: Laboratory studies of weed seed predation by carabid beetles. Proc. Int. Conf. Brighton UK 15-18 November 1999. British Crop Protection Council, Farnham, UK, pp. 571-572.

Trauttner J., Geissler S. \& Settele J. 1988: Zur Verbreitung und Ökologie des Laufkäfers Diachromus germanus (Linne 1758) (Col.: Carabidae). Mitt. Entomol. Vereins Stuttgart 23 : 86-105.

VAN DIJK T.S. 1987: The long-term effects on the carabid fauna of nutrient impoverishment of a previously arable field. Acta Phytopath. Entomol. Hung. 22: 103-118.

Volkmar C., Lübke-Al Hussein M., Richter L. \& Kreuter T. 2001: Zusammensetzung und Dynamik von Zönosen epigäischer Raubarthropoden in herbizidtoleranten bzw. konventionellen Rapsbeständen in Mitteldeutschland. Mitt. Deut. Ges. Allg. Angew. Entomol. 13: 587-590.

WeBSter F.M. 1900: Harpalus caliginonus as a strawberry pest with notes on other phytophagous Carabidae. Can. Entomol. 32: 265-271.

Westerman P., Hofman A., Vet L.E.M \& van der Werf W. 2003: Relative importance of vertebrates and invertebrates in epigaeic weed seed predation in organic cereal field. Agric. Ecosyst. Environ. 95: 417-425.

Zhang J., Drummond F. A., Liebman M. \& Hartke A. 1997: Biology of Harpalus rufipes DeGeer, an exotic ground beetle invading Maine and Northeastern North America. Trends Entomol. 1: 63-70.

ApPendix 1. Seed of the plants (seed mass, mg) used in the laboratory and field experiments. The species numbers are used throughout this paper. Nomenclature after Dostal (1989).

(1) Acetosa pratensis Mill. (0.50); (2) Achillea millefolium L. (0.82); (3) Alliaria petiolata (Bieb.) Cavara et Grande (2.27); (4) Amaranthus retroflexus L. (0.53); (5) Anagalis arvensis L. (0.43); (6) Arctium lappa L. (8.72); (7) Arenaria serpyllifolia L. (0.05); (8) Ballota nigra L. (0.65); (9) Bellis perennis L. (0.10); (10) Berteroa incana (L.) DC. (0.72); (11) Bidens tripartita L. (2.69); (12) Campanula trachelinum L. (0.18); (13) Capsella bursa-pastoris (L.) Medik. (0.23); (14) Carduus acanthoides L. (4.38); (15) Cerastium holosteoides Fries ampl. Hyl. (0.12); (16) Chamaeplium officinale (L.) Wallr. (0.32); (17) Chelidonium majus L. (0.68); (18) Chenopodium album L. (0.70); (19) Chenopodium polyspermum L. (0.27); (20) Cichorium intybus L. (1.09); (21) Cirsium arvense (L.) Scop. (0.79); (22) Consolida regalis S.F.Gray (1.38) (23) Crepis biennis L. (0.67); (24) Daucus carota L. (0.68); (25) Descurainia sophia (L.) Webb ex Prantl (0.11); (26) Erysimum cheiranthoides L. (0.29); (27) Fallopia convolvulus (L.) Á. Löve (3.90); (28) Fumaria officinalis L. (3.01); (29) Galinsoga parviflora Cav. (0.17); (30) Galium aparine L. (6.64); (31) Geranium pusillum L. (0.79); (32) Hyoscyamus niger L. (0.77); (33) Hypericum perforatum L. (0.12); (34) Jacea pratensis Lam. (1.31); (35) Lactuca serriola L. (0.42); (36) Lamium amplexicaule L. (0.67); (37) Lamium purpureum L. (0.71); (38) Lapsana communis L. (1.38); (39) Leonurus cardiaca L. (0.64); (40) Lepidium ruderale L. (0.21); 
(41) Matricaria maritima L. (0.32); (42) Medicago lupulina L. (1.81); (43) Melandrium pratense (Rafn.) Roehling (0.79); (44) Melilotus officinalis (L.) Pallas (1.81); (45) Mercurialis annua L. (2.03); (46) Origanum vulgare L. (0.05); (47) Plantago major L. (0.24); (48) Polygonum aviculare L. (1.56); (49) Portulaca oleracea L. (0.15); (50) Potentilla argentea L. (0.08); (51) Rumex crispus L. (1.44); (52) Senecio viscosus L. (0.62); (53) Sisymbrium loeselii L. (0.08); (54) Sonchus arvensis L. (0.32); (55) Stellaria media (L.) Dost. (0.42); (56) Tanacetum vulgare L. (0.09); (57) Taraxacum officinale Weber in Wiggers (0.48); (58) Thlaspi arvense L. (0.97); (59) Tithymalus exiguus (L.) Lam. (0.50); (60) Tussilago farfara L. (0.21); (61) Urtica dioica L. (0.14); (62) Urtica urens L. (0.52); (63) Veronica arvensis L. (0.47); (64) Veronica persica Poir. in Lam. (0.51); (65) Viola arvensis Murray (0.46).

APPENDIX 2. The species of carabids caught in pitfall traps in the field, some of which $\left(^{*}\right)$ were used in the laboratory experiments. In brackets: average body length (mm) according to Hurka (1996) and dry body mass (mg) calculated according to Jarosik (1989).

Acupalpus meridianus (L.) $(3.6,0.87),{ }^{*}$ Amara aenea (DeGeer) $(7.5,5.98), *$ Amara aulica (Panzer) $(12.5,22.81), *$ Amara consularis (Duftschmid) (**, 7.80), *Amara familiaris (Duftschmid) (6.4, 3.95), *Amara littorea C.G.Thomson (7.7, 6.41), *Amara ovata (F.) $(9.0,9.65),{ }^{*}$ Amara similata (Gyllenhal) $(8.7,8.83)$, *Anchomenus dorsalis (Pontoppidan) (6.8, 4.63), *Anisodactylus signatus (Panzer) $(12.5,22.81)$, Bembidion lampros (Herbst) (3.6, 0.87), Brachinus explodens Duftschmid $(6.0,3.33),{ }^{*}$ Calathus ambiguus (Paykull) (10.2, 13.39), *Calathus fuscipes (Goeze) $(11.7,19.18)$, Carabus can- cellatus Illiger (23.5, 119.26), Carabus granulatus L. (19.5, 73.15), *Dolichus halensis (Schaller) $(15.8,42.23)$, *Harpalus affinis (Schrank) $(10.2,13.39),{ }^{*}$ Harpalus atratus Latreille (9.6, 11.42), *Harpalus distinguendus (Duftschmid) (9.7, 11.74), *Harpalus signaticornis (Duftschmid) $(6.9,4.81)$, *Harpalus tardus (Panzer) $(9.7,11.74)$, Leistus ferrugineus (L.) $(7.2,5.62)$, Loricera pilicornis (F.) (7.4, 5.78), Microlestes minutulus (Goeze) (3.1, 0.59), Notiophilus palustris (Duftschmid) (5.2, 2.29), *Ophonus azureus (F.) $(7.8,6.63),{ }^{*}$ Poecilus cupreus (L.) (12.1, 20.95), *Pseudoophonus rufipes (DeGeer) (13.8, 29.57), *Pterostichus melanarius (Illiger) $(15.7,41.45)$, *Stomis pumicatus (Panzer) $(6.9,4.81),{ }^{*}$ Trechus quadristriatus (Schrank) $(3.9,1.08)$

\section{APPENDIX 3. Removal rate analysis}

The differences in seed removal were fitted by a likelihood function described by two parameters, mean time to removal, $\mu$, and shape parameter, $\alpha$. The mean time to removal was the time to when $50 \%$ of the seeds were removed. The shape parameter indicated the form of the removal curve. Proportion, $P$, of seeds that were removed as a function of time, $t$, was described as

$P(t)=e^{-\lambda+\alpha}$

where $\lambda=\mu^{-\alpha}$. The model corresponds to an exponential distribution if $\alpha$ is 1 , and to a Weibull distribution if significantly different from 1. $\alpha<1$ indicates a decrease in removal rate with time, and $\alpha>1$ increase in removal rate with time. Because the probability of seed removal always increased significantly with time $(\alpha>1)$, a Weibull function was a significantly better predictor of removal than an exponential distribution.

Received November 14, 2002, revised June 25, 2003; accepted September 2, 2003 